Article

\title{
Structural Optimization and Structure-Activity Relationship of 4-Thiazolidinone Derivatives as Novel Inhibitors of Human Dihydroorotate Dehydrogenase
}

\author{
Fanxun Zeng ${ }^{1,+}$, Lina Quan ${ }^{2,+}$, Guantian Yang ${ }^{1}$, Tiantian $\mathrm{Qi}^{2}{ }^{2}$, Letian Zhang ${ }^{1}$, Shiliang $\mathrm{Li}^{2}$, \\ Honglin $\mathrm{Li}^{2}$, Lili $\mathrm{Zhu}{ }^{2, *}$ and Xiaoyong $\mathrm{Xu}{ }^{1, *(\mathbb{C})}$ \\ 1 Shanghai Key Laboratory of Chemical Biology, School of Pharmacy, East China University of Science and \\ Technology, 130 Meilong Road, Shanghai 200237, China \\ 2 Shanghai Key Laboratory of New Drug Design, State Key Laboratory of Bioreactor Engineering, \\ School of Pharmacy, East China University of Science \& Technology, Shanghai 200237, China \\ * Correspondence: xyxu@ecust.edu.cn (X.X.); zhulfl@ecust.edu.cn (L.Z.); Tel.: +86-21-64252945 (X.X.); \\ +86-21-64253379 (L.Z.) \\ + These authors contributed equally to this work.
}

Received: 23 June 2019; Accepted: 26 July 2019; Published: 31 July 2019

\begin{abstract}
Human dihydroorotate dehydrogenase ( $h \mathrm{DHODH})$, one of the attractive targets for the development of immunosuppressive drugs, is also a potential target of anticancer drugs and anti-leukemic drugs. The development of promising $h \mathrm{DHODH}$ inhibitors is in high demand. Based on the unique binding mode of our previous reported 4-thiazolidinone derivatives, via molecular docking method, three new series 4-thiazolidinone derivatives were designed and synthesized as $h \mathrm{DHODH}$ inhibitors. The preliminary structure-activity relationship was investigated. Compound 9 of biphenyl series and compound 37 of amide series displayed IC $_{50}$ values of $1.32 \mu \mathrm{M}$ and $1.45 \mu \mathrm{M}$, respectively. This research will provide valuable reference for the research of new structures of $h \mathrm{DHODH}$ inhibitors.
\end{abstract}

Keywords: $h \mathrm{DHODH}$ inhibitors; structural optimization; structure-activity relationship; 4-thiazolidinones

\section{Introduction}

Pyrimidine, as a key precursor of RNA, DNA, glycoproteins, and phospholipids, plays a critical role in cellular metabolism and cell growth [1,2]. Human dihydroorotate dehydrogenase ( $h \mathrm{DHODH})$ is a mitochondrial enzyme that catalyzes the fourth step of de novo pyrimidine biosynthesis [3,4]. Unlike resting or fully differentiated cells which acquire pyrimidine mainly by the salvage pathways, rapidly proliferating cells, such as activated T cells, depend heavily on de novo nucleotide synthesis to meet their increased demand for nucleic acid precursors $[5,6]$. Thus, $h \mathrm{DHODH}$ would be an ideal drug target for the treatment of variety of diseases such as tumor, immunological disorders and acute myeloid leukemia [7-14].

Many $h$ DHODH inhibitors have been developed and exhibited excellent therapeutic efficacy [15]. For example, leflunomide (1, Figure 1) was approved by FDA for the treatment of rheumatoid arthritis in 1998 [16,17]. Then this compound was found to be a prodrug, forming its active metabolite teriflunomide via a base caused ring-opening reaction in vivo $[18,19]$. Teriflunomide was developed to cure multiple sclerosis later [20]. Brequinar (2), one of the strongest inhibitors of $h \mathrm{DHODH}$, only showed modest anticancer effects on a number of solid tumors in a phase II clinical trial [21,22]. Its effects 
on autoimmune diseases and viral diseases were also extensively studied [23-25]. Vidofludimus (3) was proven to be a promising pharmaceutical agent in systemic lupus erythematosus, inflammatory bowel disease, rheumatoid arthritis, and transplantation [7,26-28]. Vidofludimus also restored myeloid differentiation in leukemia cell lines at concentrations that are one log digit lower than those achieved in experiments with brequinar [14]. The development of mL390 (4) that induced differentiation in acute myeloid leukemia (AML) demonstrated that the inhibition of $h \mathrm{DHODH}$ could overcome differentiation blockade in AML [29]. Recently compound 5 was reported to reduce tumor growth by increasing p53 synthesis [30]. Compound 6 showed brequinar-like $h \mathrm{DHODH}$ potency in vitro and was superior in terms of cytotoxicity and immunosuppression. In general, it is significant to develop promising $h \mathrm{DHODH}$ inhibitors for the severe side effects of leflunomide/teriflunomide and the lack of newly marketed $h \mathrm{DHODH}$ inhibitors.<smiles>Cc1oncc1C(=O)Nc1ccc(C(F)(F)F)cc1</smiles>

1: Leflunomide<smiles>C/C(O)=C(/C#N)C(=O)Nc1ccc(C(F)(F)F)cc1</smiles>

Teriflunomide, $\mathrm{IC}_{50}=0.13 \mu \mathrm{M}$<smiles>Cc1c(-c2ccc(-c3ccccc3F)cc2)nc2ccc(F)cc2c1C(=O)O</smiles>

2: Brequinar, $\mathrm{IC}_{50}=0.01 \mu \mathrm{M}$

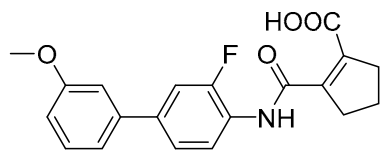

3: Vidofludimus, $\mathrm{IC}_{50}=0.134 \mu \mathrm{M}$

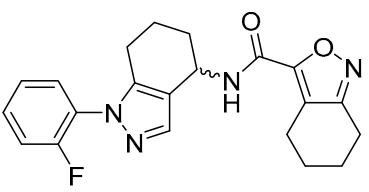

5: $\mathrm{IC}_{50}=0.032 \mu \mathrm{M}$<smiles>O=C(CCNC(=O)c1ccc(OC(F)(F)F)cc1)N[C@H]1CCCc2ccccc21</smiles>

4: $\mathrm{IC}_{50}=0.56 \mu \mathrm{M}$<smiles>O=C(Nc1c(F)c(F)c(-c2ccccc2)c(F)c1F)c1c(O)nn2ccccc12</smiles>

6: $\mathrm{IC}_{50}=0.75 \mu \mathrm{M}$

Figure 1. Structures of representative inhibitors of $h \mathrm{DHODH}$.

Recently we had described 4-thiazolidinone derivatives 7 and 8 as novel $h$ DHODH inhibitors [31]. It was found that the binding mode of 4-thiazolidinone with $h \mathrm{DHODH}$ was different from the classic inhibitors, that is, the thiazolidinone fragment locates at the outside of the bind pocket, cyano group contacts ALA-59 by a water-mediated hydrogen bond, carbonyl and TYR-38 forms hydrogen bond interaction, while the aromatic fragment contacts MET-43 by hydrophobic interaction (Figure 2A). But, it was found that compound 8 only occupies the hydrophobic subsite of the ubiquinone-binding site with its naphthalenyl group (Figure 2B,C) [31]. The binding mode of compound 8 suggested us that the replacement of its naphthalenyl group with a suitable longer aryl group could orient the new ligand towards the inner side of the binding site. An additional polar group, such as carboxyl and acetyl, would generate hydrogen bond or salt bridge interactions with residue Arg-136 in the hydrophilic subsite of the ubiquinone-binding site and may improve compounds' binding affinity against $h \mathrm{DHODH}$. Therefore, further structural optimization of 4-thiazolidinone derivatives that focused on the decoration of the aryl group to identify more potent $h \mathrm{DHODH}$ inhibitors was presented in this study. 


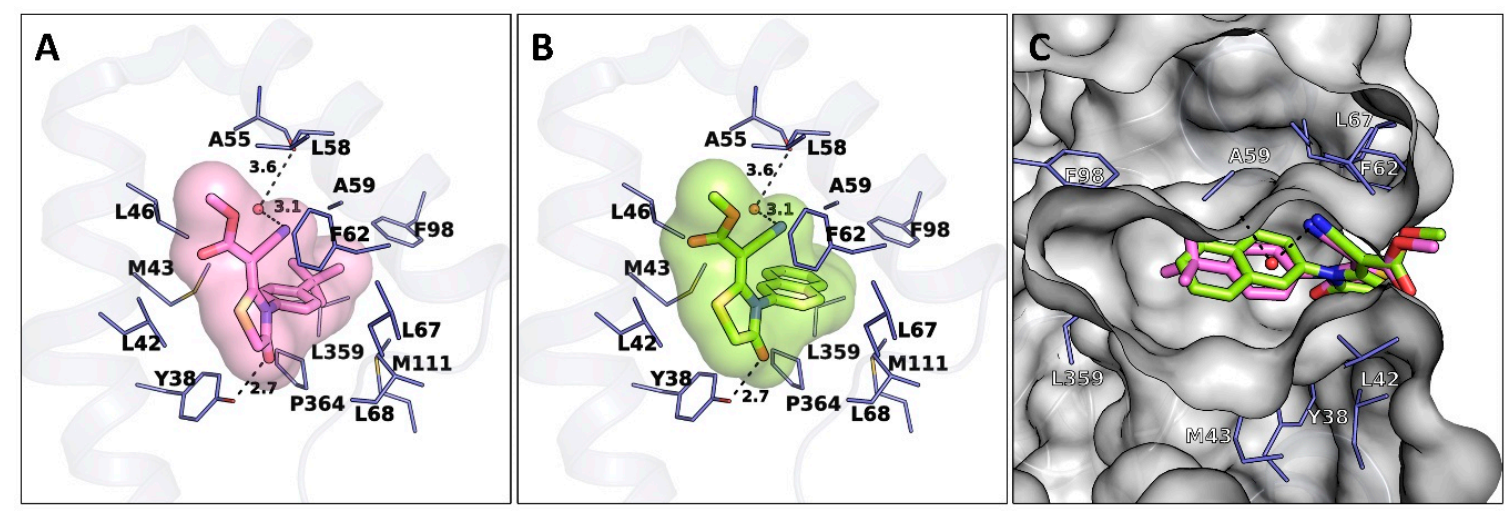

Figure 2. Proposed binding modes of 4-thiazolidinone derivatives 7 (A) and 8 (B). The X-ray crystal structure of $h \mathrm{DHODH}$ with PDB ID of 4LS1 was used in molecular docking. Figure 2C is an overlay of compounds 7 and 8.

\section{Results and Discussion}

\subsection{Molecular Design Strategies}

In order to probe the inner subsite of the ubiquinone-binding site of $h \mathrm{DHODH}$, biphenyl derivatives were firstly designed and synthesized. The binding mode of $\mathbf{9}$ was simulated using the same molecular docking method reported previously [31,32]. It was shown that the introduction of 4-phenyl moiety could enhance the hydrophobic interaction between the biphenyl compounds and the binding pocket (Figures 3 and 4). In addition, by observing the binding modes of $\mathbf{9}$, we found that there is some space for substitution at the ortho-position of the phenyl group to enhance the hydrophobic interactions with residues Met43, Leu46, Met111 and Pro364. Therefore, we tried to introduce a small fluorine atom into the structure and synthesized compounds 10-18. However, compared with brequinar, a para-phenyl might collide with the binding pocket, which would influence the binding affinity against the target $h \mathrm{DHODH}$ (Figure 3). Therefore, phenoxy (phenoxymethyl) and phenyl amide groups were introduced to improve the binding strength by adjusting the molecular configuration (Figure 5). After molecular docking simulations, it was found that the introduction of an ether bond could cause an angle (about $109^{\circ}$ ) to adjust the orientation of the phenyl group, which may be helpful to avoid the steric hindrance between the ligand and the receptor (Figure 5). If the linker was replaced by a longer amide bond, the whole molecule would also become longer, thus enabling the phenyl group to contact residues in the inner binding site. When substituting a carboxyl group to the meta-position of the phenyl group of the benzamide derivatives next, the carboxyl group would form hydrogen bond interactions with residues Gln47 and Arg136, which are beneficial for strengthening the binding affinity of the compounds (Figure 6). In addition, the amide bond could participate in a water-mediated hydrogen bond network, which may be favorable for molecular binding. The results of docking simulations suggested us that the design strategies may be feasible to improve the potency of the compounds. The detailed modification strategies are described in Figures 4 and 7.

\subsection{Chemistry}

Key intermediates of compounds 9-26 were synthesized according to Scheme 1. Compounds $\mathbf{9 c}-\mathbf{1 8 c}$ were obtained by Suzuki cross-coupling reactions of compounds $\mathbf{9 a}-\mathbf{1 8 a}$ with $\mathbf{9 b} \mathbf{- 1 8 b}$. Etherification of compounds 19a-22a with 1-fluoro-4-nitrobenzene yielded compounds $\mathbf{1 9 b} \mathbf{- 2 2} \mathbf{b}$, which were reduced to afford compounds $19 \mathrm{c}-\mathbf{2 2 c}$. Phenol was coupled with 1-fluoro-4-nitrobenzene to give compound 23a. Etherification of (bromomethyl) benzene with 4-nitrophenol afforded compound 24a, which was reduced to give compound $\mathbf{2 4 b}$. Compounds $\mathbf{2 5 b}$ and $\mathbf{2 6 b}$ were obtained by etherification of compounds 25a, 26a with 4-nitrophenol, which were further reduced and hydrolyzed to give compounds $25 \mathrm{~d}$ and $26 \mathrm{~d}$. 


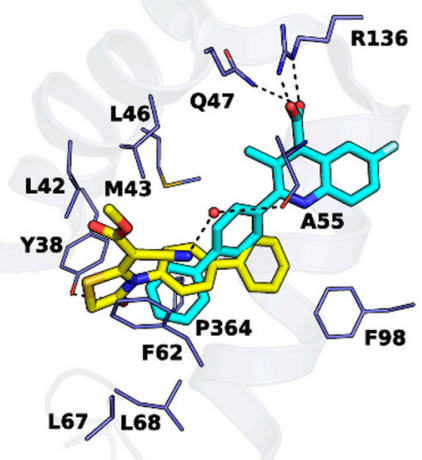

Figure 3. Binding mode of 4-thiazolidinone derivative 9. Compound 9 is displayed as yellow sticks and brequinar is shown as cyan sticks.

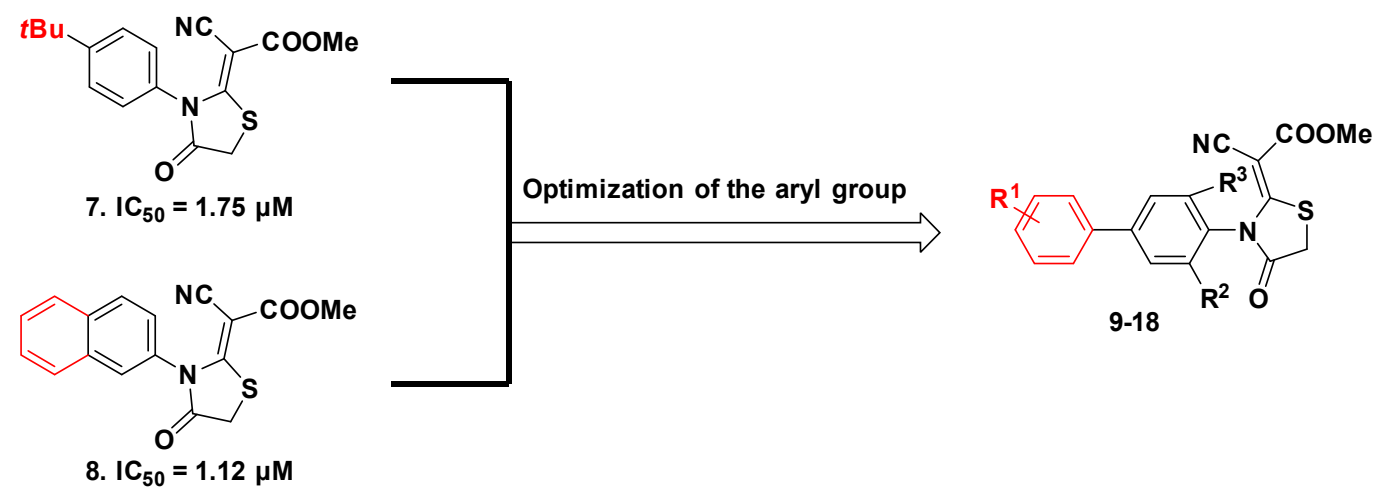

Figure 4. Molecular design strategies of 4-thiazolidinones with biphenyl as $h \mathrm{DHODH}$ inhibitors.

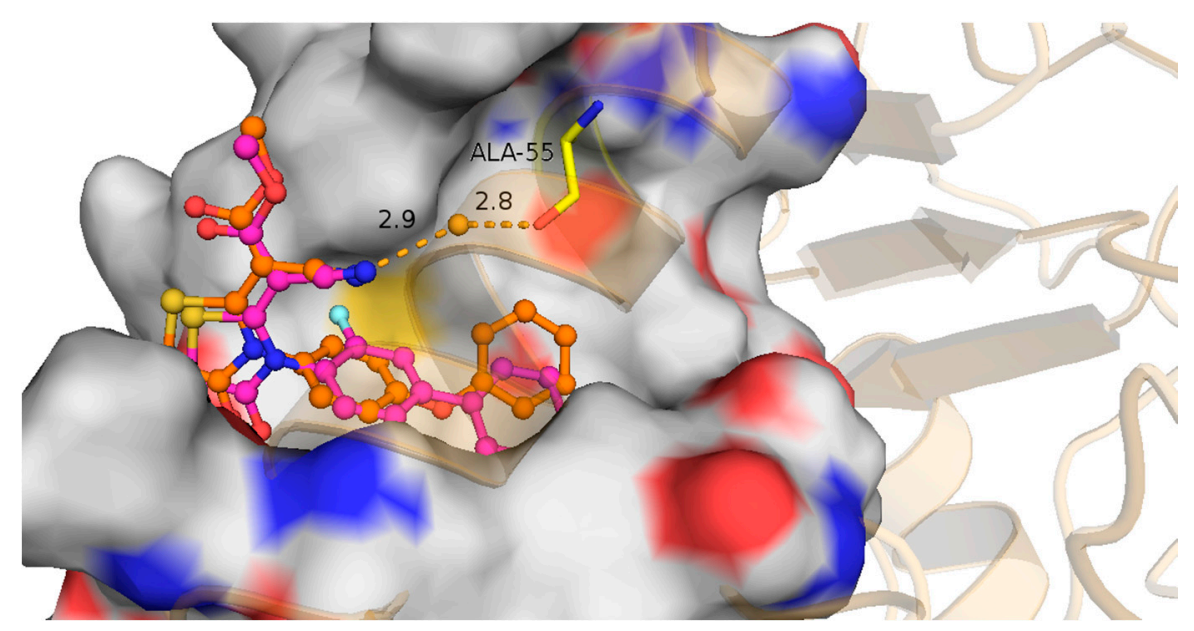

Figure 5. Binding modes of 4-thiazolidinones with biphenyl ether structure (magenta sticks: compound 10, orange sticks: compound 19). 


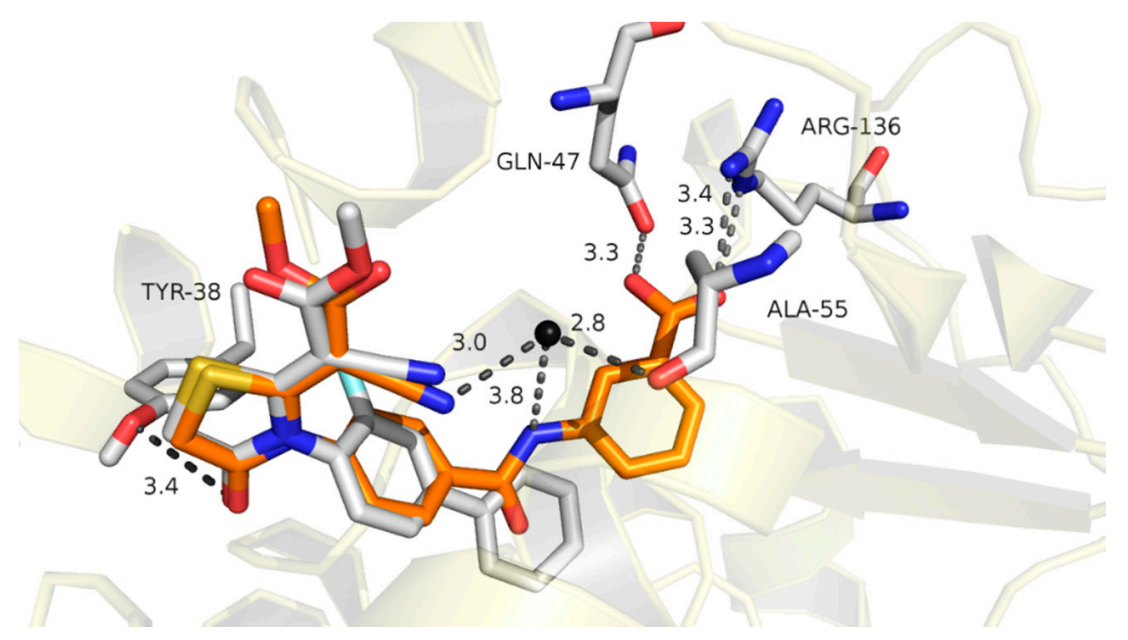

Figure 6. Proposed binding mode of benzamide-substituted 4-thiazolidinones as $h$ DHODH inhibitors (orange sticks: compound 41, gray sticks: compound 10).

biphenyl structure
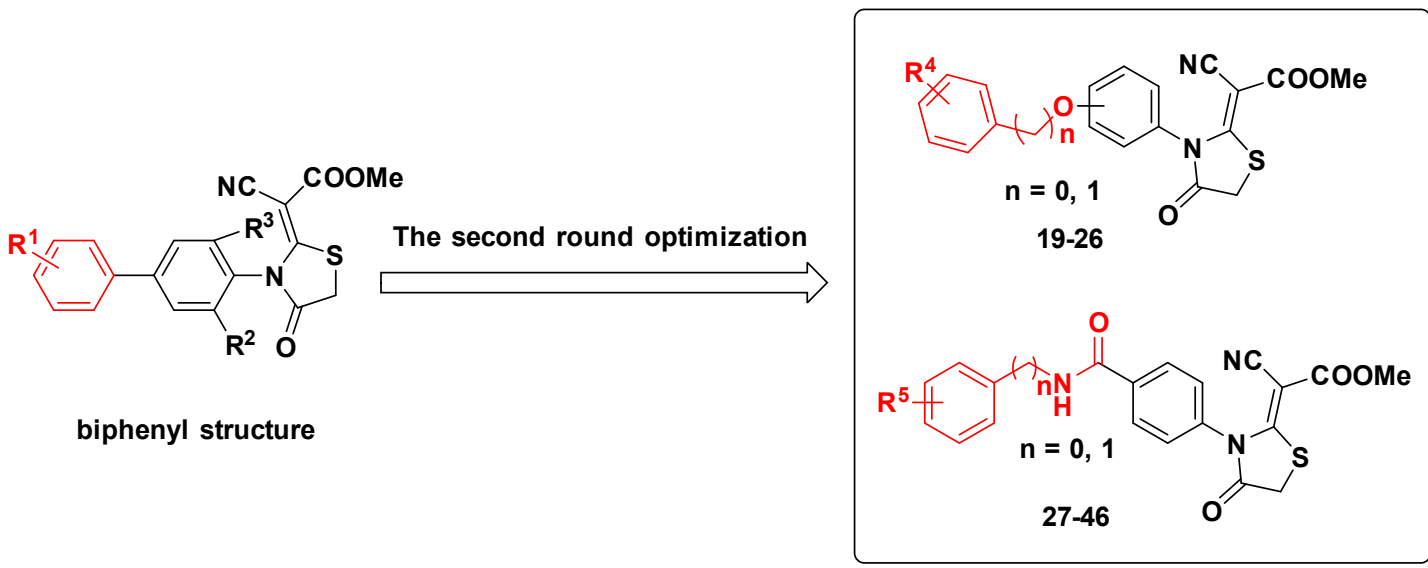

Figure 7. Design and modification strategies of 4-thiazolidinones with biphenyl ether and amide as $h$ DHODH inhibitors.

Compound IM and key intermediates of compounds 40-46 were obtained according to Scheme 2. 4-isothiocyanatobenzoic acid was prepared by reaction of 4-aminobenzoic acid with 1,1'-thiocarbonyldiimidazole (TCDI) in the presence of TEA. 4-Isothiocyanatobenzoic acid was treated with methyl 2-cyanoacetate and potassium hydroxide in DMF to provide ketene-N, S-acetal salt, which then reacted with 2-chloroacetyl chloride to give key intermediate IM.

Compounds 40c, 41c were obtained by reduction of compounds $40 \mathrm{~b}, 41 \mathrm{~b}$, which were prepared by amidation reactions of compounds $40 a, 41 a$ with 4-nitrobenzoyl chloride. Compound 42b was synthesized by hydrazinolysis of compound $42 a$, which was prepared by reaction of phthalide with potassium phthalimide.

The important intermediate 43c was generated from starting material 3-cyanobenzoic acid via protection, reduction, and amidation. Compound 44e was prepared from 1-(tert-butyl)-2methylbenzene via oxidation, nitration, reduction, amidation, and reduction.

Compound 45 b was synthesized by amination of compound $45 a$, which was obtained by Friedel -Crafts acylation of 2-bromonaphthalene. Intermediate $46 \mathrm{~b}$ was obtained by removing Boc group of compound 46a, which was obtained by amination of IM. 
(a):

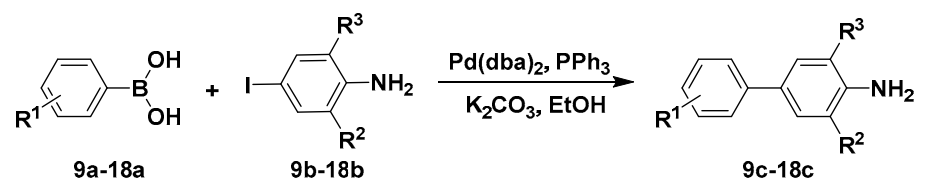

(b):

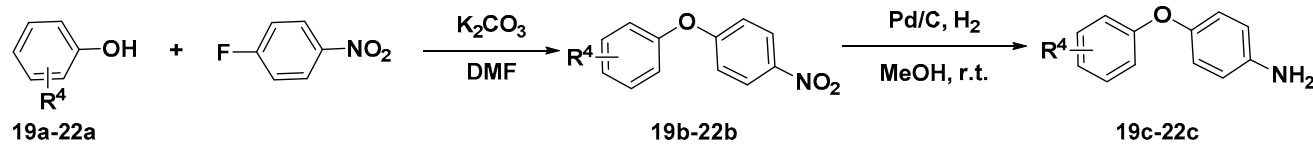

(c):
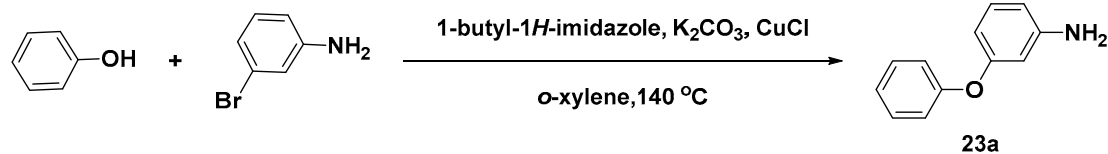

(d):
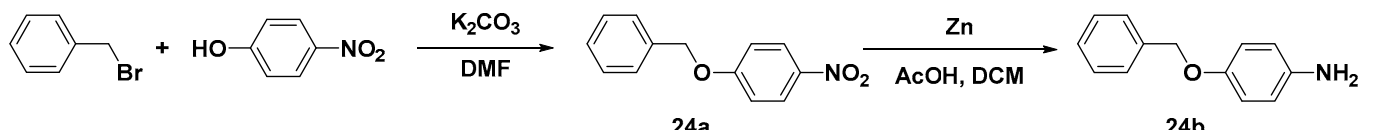

24a

24b

(e):
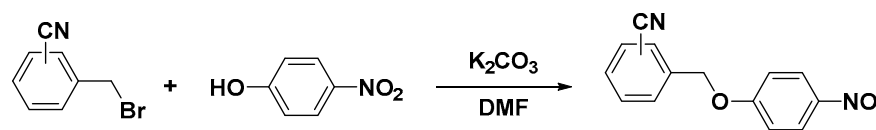

25b, 26b
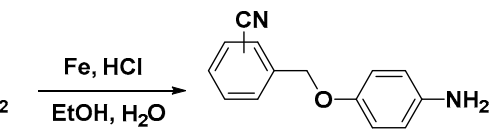

$25 a, 26 a$



$25 c, 26 c$

Scheme 1. Synthesis of key intermediates of compounds 9-26.

The synthetic route to obtain target compounds 9-46 was shown in Scheme 3. Isothiocyanates 9e-22e, 23c, and 24d were obtained from corresponding aryl amines by two-step reactions. Key intermediates 25e, 26e, 40d, 41d, 44f and compounds 9-26, 40, 41, 44 were prepared by the same route of 4-isothiocyanatobenzoic acid and IM, respectively. Compounds 27-39, 42, and 45 were generated by amination of intermediates 27a-39a, 42b, 45b with IM. Compound 43 was afforded by deprotection of compound 43 . The imidization of $46 \mathrm{~b}$ with 2 -formylbenzoic acid was introduced to give compound 46 .

\subsection{Inhibitory Activities against hDHODH and SAR Study}

In order to identify more potent compounds, biphenyl group was introduced for the size and hydrophobicity of the aryl group which is essential for the activities. As shown in Table 1, the activity of unsubstituted biphenyl derivative 9 was equal to that of compounds 7 and 8 . Introducing a fluorine atom into the biphenyl group (compounds 10 and 11) decreased the inhibitory activities. 2'-Methyl analog 12 had slightly less activity than 10. Introduction of a methoxy group into the $2^{\prime}-, 3^{\prime}-$, or $4^{\prime}$-positions of the biphenyl group (compounds 13-15) resulted in roughly 2-fold reduction in inhibitory activity compared to compound 10, amongst the three compounds, the $3^{\prime}$-methoxy derivative 14 was slightly more potent than compounds 13, 15. Introduction of electron-withdrawing groups (compounds 16-18) also failed to enhance the potency. Moreover, the results of the bioassay also showed that the ortho-substituted fluorine atom (compounds 10 and 11) did not make a positive contribution to the binding affinity, indicating that there may be steric clashes. 
(a): $\mathrm{HOOC}-\mathrm{NH}_{2}+\mathrm{TCDI} \frac{\mathrm{TEA}}{\mathrm{DCM}, \text { r.t. }} \mathrm{HOOC}-\mathrm{NCS} \underset{\mathrm{CICH}_{2} \mathrm{COCI}, \mathrm{KOH}, \mathrm{DMF}}{\mathrm{NC} \text { COOMe }}$ (b):



(c):

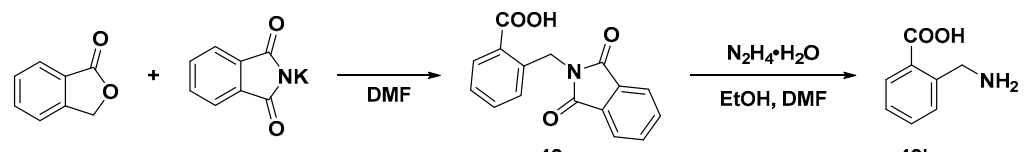

(d):
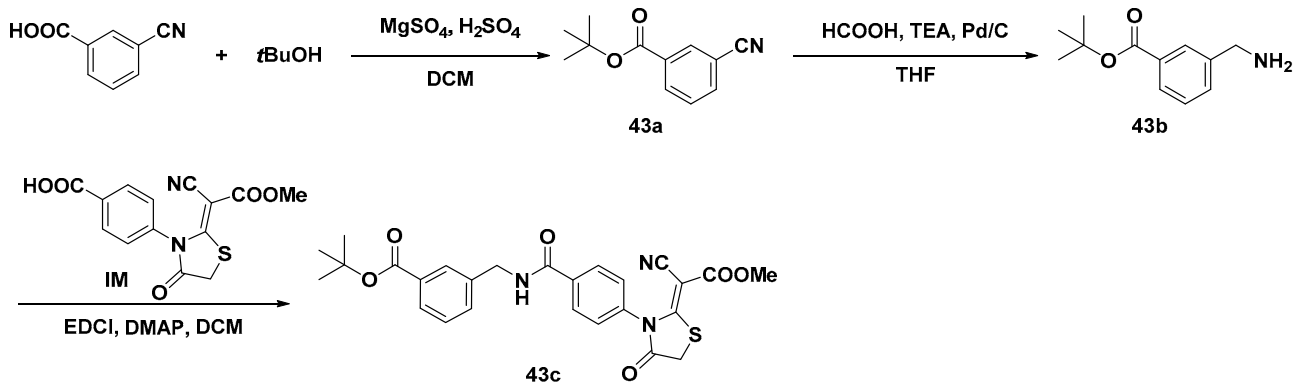

(e):
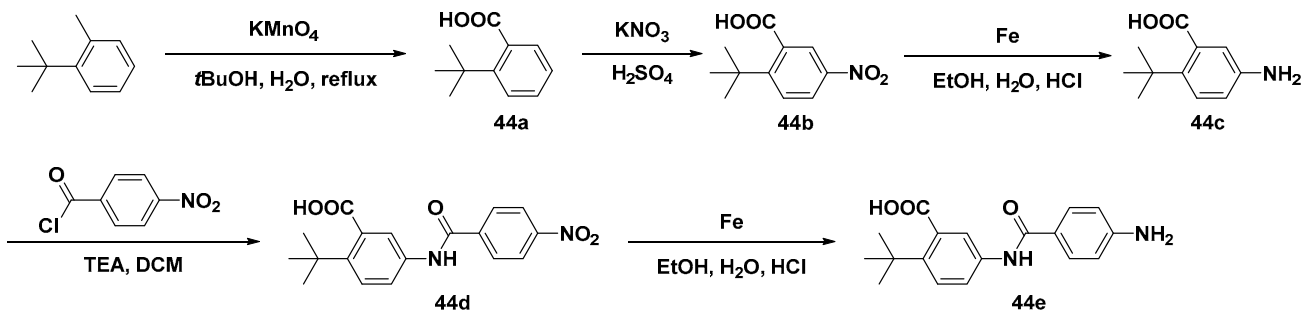

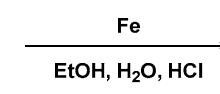

EtOH, $\mathrm{H}_{2} \mathrm{O}, \mathrm{HCl}$

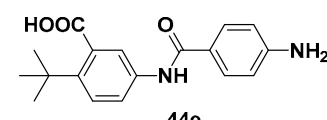

$44 \mathrm{e}$

(f):

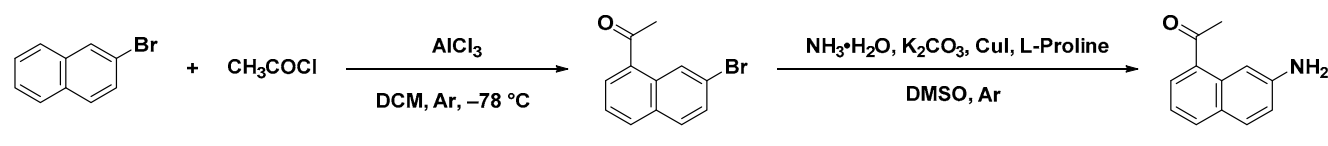

$45 \mathrm{a}$

$45 b$<smiles>COC(=O)C(C)=C1SCC(=O)N1c1ccc(C(=O)NCNC(=O)c2ccc(N3C(=O)CSC3=C(C(=O)OC)C(=O)OCC(C)(C)C)cc2)cc1</smiles>

Scheme 2. Synthesis of IM and key intermediates of compounds 40-46.

Since the biphenyl derivatives only showed moderate potency, biphenyl groups were replaced further by flexible aryl ethers further (Table 2). To our disappointment, diphenyl ether derivatives 19-23 displayed markedly diminished activity. The 3-phenoxyphenyl analog 23 was also inactive. Benzyl ether derivative 24 exhibited moderate activity with an $\mathrm{IC}_{50}$ value of $4.32 \mu \mathrm{M}$. The activity decreased when a carboxyl group (compounds 25 and 26) was introduced. 


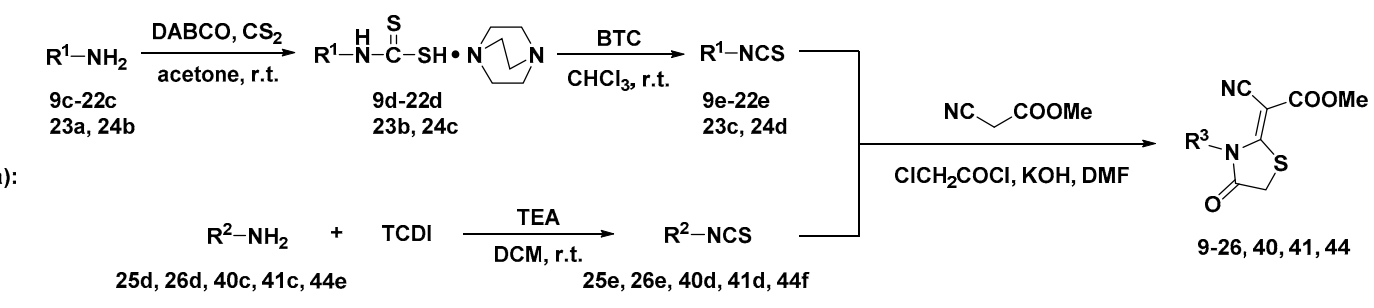

(b):

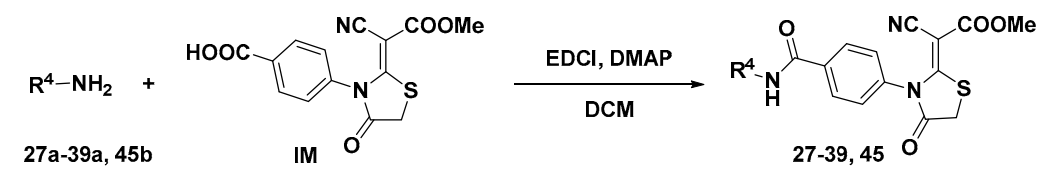

(c):

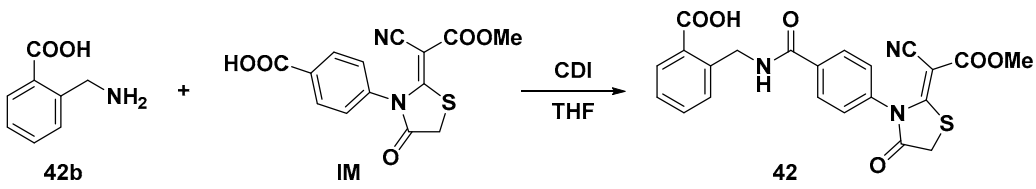

(d):

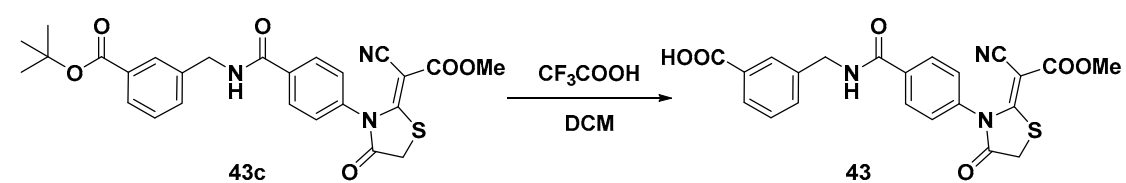

(e):



Scheme 3. Synthesis of compounds 9-46.

Table 1. Structures and activities for 4-thiazolidinone analogs 9-18<smiles>[R]N1C(=O)CS/C1=C(/C#N)C(C)=O</smiles>

\begin{tabular}{|c|c|c|c|}
\hline Compd & $\mathbf{R}$ & $\%$ Inhibition at $10 \mu \mathrm{M}$ & $h \mathrm{DHODH} \mathrm{IC}_{50}{ }^{a}(\mu \mathrm{M})$ \\
\hline 7 & & 79.1 & 1.75 \\
\hline 8 & & 80.3 & 1.12 \\
\hline 9 & & 73.8 & 1.32 \\
\hline 10 & & 58.8 & 3.52 \\
\hline 11 & & 33.9 & $>10$ \\
\hline 12 & & 57.6 & 6.04 \\
\hline
\end{tabular}


Table 1. Cont.

Compd

${ }^{a} \mathrm{IC}_{50}$ values were determined from three independent tests, and attempts to determine $\mathrm{IC}_{50}$ values were made if the inhibition rate at $10 \mu \mathrm{M}$ was greater than $50 \%$.

Table 2. Structures and activities for 4-thiazolidinone analogs 19-46.

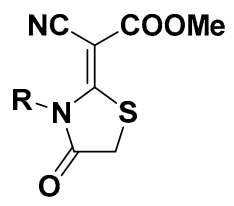

\begin{tabular}{|c|c|c|c|}
\hline Compd & $\mathbf{R}$ & $\%$ Inhibition at $10 \mu \mathrm{M}$ & $h \mathrm{DHODH} \mathrm{IC}_{50}(\mu \mathrm{M})$ \\
\hline 19 & & 52.0 & 9.43 \\
\hline 20 & & 44.7 & $>10$ \\
\hline 21 & & 29.7 & $>10$ \\
\hline 22 & & 18.1 & $>10$ \\
\hline 23 & & 34.4 & $>10$ \\
\hline 24 & & 55.4 & 4.32 \\
\hline 25 & & 29.9 & $>10$ \\
\hline 26 & & 36.2 & $>10$ \\
\hline 27 & & 41.7 & $>10$ \\
\hline
\end{tabular}


Table 2. Cont.

\begin{tabular}{|c|c|c|c|}
\hline Compd & $\mathbf{R}$ & $\%$ Inhibition at $10 \mu \mathrm{M}$ & $h \mathrm{DHODH} \mathrm{IC}_{50}(\mu \mathrm{M})$ \\
\hline 28 & & 69.0 & 2.98 \\
\hline 29 & & 47.0 & $>10$ \\
\hline 30 & & 71.3 & 3.01 \\
\hline 31 & & 53.6 & 8.56 \\
\hline 32 & & 52.7 & 7.50 \\
\hline 33 & & 42.0 & $>10$ \\
\hline 34 & & 38.1 & $>10$ \\
\hline 35 & & 24.5 & $>10$ \\
\hline 36 & & 55.4 & 5.01 \\
\hline 37 & & 75.6 & 1.45 \\
\hline 38 & & 38.2 & $>10$ \\
\hline 39 & & 39.9 & $>10$ \\
\hline 40 & & 34.5 & $>10$ \\
\hline 41 & & 23.5 & $>10$ \\
\hline 42 & & 36.8 & $>10$ \\
\hline 43 & & 44.0 & $>10$ \\
\hline 44 & & 30.3 & $>10$ \\
\hline 45 & & 42.2 & $>10$ \\
\hline 46 & & 34.8 & $>10$ \\
\hline
\end{tabular}


Then the moderate rigid and longer amide structure was introduced as a linker (compounds 27-46, Table 2). Phenyl derivative $\mathbf{2 8}$ showed a moderate activity, while the cyclohexyl analog $\mathbf{2 7}$ gave a dramatically decreased activity. It indicated that rigid aromatic ring is better than flexible cyclohexyl ring. Next we tried to introduce substituent groups into the phenyl group. A 4-tert-butyl substituent (compound 37) was tolerated, while the introduction of smaller substituent groups such as $\mathrm{CH}_{3}, \mathrm{~F}, \mathrm{Cl}$, $\mathrm{I}, \mathrm{CF}_{3}, \mathrm{OCH}_{3}, \mathrm{CN}$ etc. into the 2, 3 or 4-positions (compounds 29-36) was detrimental to the activity. The naphthalen-2-yl derivative 38 and benzyl derivative 39 were inactive. Subsequently, $\mathrm{COOH}$ and carbonyl groups were introduced to generate hydrogen bonds or salt bridge interactions with residue Arg136 in the hydrophilic subsite of the ubiquinone-binding site. However, the inhibition rates of the corresponding analogs $\mathbf{4 0 - 4 6}$ at $10 \mu \mathrm{M}$ were still less than $50 \%$. The bioassay results did not match our modeling results. It indicated that neither ether nor amide is an appropriate linker to extend the molecules to fit well in the pocket and eventually contact the inner residues Arg136 and Gln47.

Although the introduction of a biphenyl, diphenyl ether and amide structures into 4- thiazolidinone did not obviously increase the rate of inhibition of $h \mathrm{DHODH}$, the attempts can provide some ideas for $h \mathrm{DHODH}$ inhibitor lead identification. We speculate that there may exist steric clashes caused by inappropriate biphenyl, ether and amide group linkers. Thus, we will try some other linkers like $-\mathrm{C}=\mathrm{N}-\mathrm{N}-,-\mathrm{C}-\mathrm{C}(=\mathrm{O})-$, and $-\mathrm{C}-\mathrm{C}(=\mathrm{O})-\mathrm{C}$ - to replace the $\mathrm{O}$ of biphenyl ether or the CONH of the amide series in our future work to further investigate the SAR and to obtain more potent DHODH inhibitors. In addition, it was found that any changes to the structure connecting the $\mathrm{N}$-terminus of thiazolidone have a weak influence on the bioactivities, which means that thiazolidone is important to increase the activity. In our future work, we will try to select other heterocycles and investigate the stability of thiazolidones under the determination conditions to further establish the factors influencing the bioactivity.

\section{Materials and Methods}

\subsection{General Information}

Unless otherwise indicated, all commercially available solvents and reagents were purchased directly from commercial suppliers and used as received without further purification. Melting points (m.p.) were recorded on Büchi B540 apparatus (Büchi Labortechnik AG, Flawil, Switzerland) and are uncorrected. ${ }^{1} \mathrm{H}-\mathrm{NMR},{ }^{19} \mathrm{~F}-\mathrm{NMR}$ and ${ }^{13} \mathrm{C}$-NMR spectra were recorded on an AM-400 $\left({ }^{1} \mathrm{H}\right.$ at $400 \mathrm{MHz}$, ${ }^{13} \mathrm{C}$ at $100 \mathrm{MHz},{ }^{19} \mathrm{~F}$ at $376 \mathrm{MHz}$ ) spectrometer (Bruker BioSpin AG, Fällanden, Switzerland) with $\mathrm{CDCl}_{3}$ or DMSO- $d_{6}$ as the solvent and TMS as the internal standard. Chemical shifts are reported in $\delta$ (parts per million) values. The following abbreviations were used to explain the multiplicities: $\mathrm{s}=$ singlet, $\mathrm{d}=$ doublet, $\mathrm{t}=$ triplet, $\mathrm{q}=$ quartet, $\mathrm{m}=$ multiplet, coupling constant $(\mathrm{Hz})$ and integration. High-resolution electron mass spectra (ESI-TOF) were performed on a Micromass LC-TOF spectrometer (Waters Co.,Ltd., Milford, MA, USA). High resolution mass spectra (HRMS) were recorded under electron impact $(70 \mathrm{eV})$ conditions using a MicroMass GCT CA 055 instrument (Waters Co.,Ltd., Milford, MA, USA). Analytical thin-layer chromatography (TLC) was carried out on precoated plates (silica gel 60 F254) and spots were visualized with ultraviolet (UV) light.

\subsection{Chemistry}

\subsubsection{Synthesis of Key Intermediates of Compounds 9-26.}

General Procedure for the Synthesis of Intermediates $\mathbf{9 c}-\mathbf{1 8 c}$

Substituted 4-iodoanilines $\mathbf{9 b} \mathbf{- 1 8} \mathbf{b}$ ( $5 \mathrm{mmol})$, substituted phenylboronic acids $\mathbf{9 a - 1 8 a}(6 \mathrm{mmol})$, an orange solution of $\mathrm{Pd}(\mathrm{dba})_{2}(2 \mathrm{~mol} \%)$ and triphenylphosphine $(6 \mathrm{~mol} \%)$ were added in a tube. The tube was evacuated and back-filled with argon. Potassium carbonate $(20 \mathrm{mmol})$ solution $(10 \mathrm{~mL}, 2 \mathrm{~mol} / \mathrm{L})$ and ethanol $(10 \mathrm{~mL})$ were added using syringe, and the mixture was stirred and refluxed for $3-5 \mathrm{~h}$. After completion of the reaction, the reaction solution was extracted three times with ethyl acetate. 
The combined organic phases were dried over $\mathrm{Na}_{2} \mathrm{SO}_{4}$, and the solvent was removed under reduced pressure. The residue was purified by column chromatography (Petroleum ether (PE)/Ethyl acetate $(E A)=10: 1, V / V)$, to give $\mathbf{9 c}-\mathbf{1 8 c}$ in $65 \%-95 \%$ yield. (Spectrums for target compounds $\mathbf{7 - 4 6}$ could be accessed in Supplementary Materials).

General Procedure for the Synthesis of Intermediates 19b-22b

$\mathrm{K}_{2} \mathrm{CO}_{3}(50 \mathrm{mmol})$ was carefully added to a solution of $19 \mathrm{a}-22 \mathrm{a}(12 \mathrm{mmol})$ and 1-fluoro-4nitrobenzene $(10 \mathrm{mmol})$ in DMF $(8 \mathrm{~mL})$. The mixture was stirred at heating condition $\left(120^{\circ} \mathrm{C}\right.$ for $\mathbf{1 9 b}$, $20 \mathbf{b}$, and $22 \mathbf{b}, 60^{\circ} \mathrm{C}$ for $\mathbf{2 1 b}$ ) until the reaction was complete. The reaction mixture was diluted with water $(20 \mathrm{~mL})$, extracted with EA after cooling to room temperature. The combined organic layer was washed with $1 \mathrm{M} \mathrm{NaOH}, 1 \mathrm{M} \mathrm{HCl}$ and saturated salt water in order. Then the mixture was dried $\left(\mathrm{Na}_{2} \mathrm{SO}_{4}\right)$, concentrated under reduced pressure to give $\mathbf{1 9} \mathbf{b}-\mathbf{2 2} \mathbf{b}$ in yield of $70-90 \%$, which was used in the next step without further purification.

General Procedure for the Synthesis of Intermediates 19c-22c

Compounds $\mathbf{1 9 b}-\mathbf{2 2} \mathbf{b}(8 \mathrm{mmol})$ and $\mathrm{Pd} / \mathrm{C}(10 \% \mathrm{w} / \mathrm{w})$ were added to $\mathrm{MeOH}(40 \mathrm{~mL})$. The resulted mixture was reacted under $\mathrm{H}_{2}$ atmosphere at room temperature for $2 \mathrm{~h}$. The mixture was filtered and the filtrate was concentrated under reduced pressure to give $19 \mathrm{c}-22 \mathrm{c}$ in yield of $95-98 \%$, which was used in the next step without further purification.

Synthesis of Intermediate 23a

Phenol (12 mmol), 3-bromoaniline (10 mmol), $\mathrm{K}_{2} \mathrm{CO}_{3}(20 \mathrm{mmol}), 1$-butyl-1H-imidazole (5 mmol), and $\mathrm{CuCl}(4.5 \mathrm{mmol})$ were added to o-xylene $(10 \mathrm{~mL})$ under Ar atmosphere, and the mixture was heated to $140{ }^{\circ} \mathrm{C}$ for $20 \mathrm{~h}$. After cooling to room temperature, the mixture was filtered. The filtrate was concentrated under reduced pressure and purified by column chromatography (PE/EA=4:1, V/V) to give 23a in yield of $90 \%$.

Synthesis of Intermediate 24a

$\mathrm{K}_{2} \mathrm{CO}_{3}(20 \mathrm{mmol})$ was added to a solution of (bromomethyl)benzene $(12 \mathrm{mmol})$ and 4-nitrophenol $(10 \mathrm{mmol})$ in DMF $(10 \mathrm{~mL})$. The resulted mixture was allowed to react at $90^{\circ} \mathrm{C}$ for $2 \mathrm{~h}$. The mixture was diluted with water $(50 \mathrm{~mL})$ after cooling to room temperature. The resulted mixture was filtered, washed with water. The filter cake was further crystallized from $\mathrm{EtOH}$ to give target compound in yield of $80 \%$.

Synthesis of Intermediate $\mathbf{2 4 b}$

Zinc powder $(120 \mathrm{mmol})$ and $\mathrm{AcOH}(400 \mathrm{mmol})$ were added to a solution of $24 \mathrm{a}(8 \mathrm{mmol})$ in DCM $(45 \mathrm{~mL})$ in ice bath. The mixture was stirred at room temperature until the reaction was completed. The reaction mixture was filtered. The filtrate was washed with water, dried $\left(\mathrm{Na}_{2} \mathrm{SO}_{4}\right)$ and concentrated under reduced pressure. The residue was further purified by column chromatography (PE/EA=4:1, $\mathrm{V} / \mathrm{V})$ to give $24 \mathrm{~b}$ in yield of $80 \% .{ }^{1} \mathrm{H}-\mathrm{NMR}\left(\mathrm{CDCl}_{3}\right): \delta 7.39-7.31(\mathrm{~m}, 4 \mathrm{H}) 7.27(\mathrm{~d}, J=6.4 \mathrm{~Hz}, 1 \mathrm{H}), 6.69$ $(\mathrm{d}, J=8.4 \mathrm{~Hz}, 2 \mathrm{H}), 6.55(\mathrm{~d}, J=8.4 \mathrm{~Hz}, 2 \mathrm{H}), 4.27(\mathrm{~s}, 2 \mathrm{H}), 4.16(\mathrm{~s}, 2 \mathrm{H}) \mathrm{ppm} ;{ }^{13} \mathrm{C}-\mathrm{NMR}\left(\mathrm{CDCl}_{3}\right): \delta 147.79$, $142.42,139.61,128.62,127.60,127.22,116.21,114.37,49.36 \mathrm{ppm}$.

General Procedure for the Synthesis of Intermediates $\mathbf{2 5 b}$ and $\mathbf{2 6 b}$

$\mathrm{K}_{2} \mathrm{CO}_{3}(15 \mathrm{mmol})$ was added to a solution of compounds $25 \mathbf{a}$, $26 \mathbf{b}(10 \mathrm{mmol})$, and 4-nitrophenol (11 mmol) in DMF (30 mL) under Ar atmosphere, and the mixture was heated to $120^{\circ} \mathrm{C}$ for $4 \mathrm{~h}$. The mixture was diluted with water $(50 \mathrm{~mL})$ after cooling to room temperature. The resulted mixture was filtered, washed with water. The filter cake was dried to give target compounds $\mathbf{2 5 b}$ and $\mathbf{2 6} \mathbf{b}$. 
2-((4-Nitrophenoxy)methyl)benzonitrile (25b): ${ }^{1} \mathrm{H}-\mathrm{NMR}\left(\mathrm{CDCl}_{3}\right): \delta 8.26-8.21(\mathrm{~m}, 2 \mathrm{H}), 7.75(\mathrm{~d}, J=7.6 \mathrm{~Hz}$, 1H), 7.70-7.64 (m, 2H), 7.52-7.47 (m, 1H), 7.11-7.06 (m, 2H). $5.35(\mathrm{~s}, 2 \mathrm{H}) \mathrm{ppm} ;{ }^{13} \mathrm{C}-\mathrm{NMR}\left(\mathrm{CDCl}_{3}\right): \delta$ $162.97,142.20,138.97,133.27,133.15,129.05,128.63,126.04,116.85,114.91,111.50,68.16$ ppm.

General Procedure for Synthesis of Intermediates 25c and 26c

Reduced iron powder $(100 \mathrm{mmol})$ and concentrated hydrochloric acid $(0.5 \mathrm{~mL})$ were carefully added to a mixture of compounds $\mathbf{2 5} \mathbf{b}, \mathbf{2 6} \mathbf{b}, \mathrm{EtOH}(60 \mathrm{~mL})$ and water $(6 \mathrm{~mL})$. The reaction was reacted under reflux condition until the reaction was completed. The reaction mixture was filtered and the filter cake was washed with some EA. The filtrate was concentrated and used in the next step without further purification.

3-((4-Aminophenoxy)methyl)benzonitrile (26c): ${ }^{1} \mathrm{H}-\mathrm{NMR}\left(\mathrm{CDCl}_{3}\right): \delta 7.68(\mathrm{~d}, J=7.6 \mathrm{~Hz}, 2 \mathrm{H}), 7.61(\mathrm{t}$, $J=7.6 \mathrm{~Hz}, 1 \mathrm{H}), 7.40(\mathrm{t}, J=7.6 \mathrm{~Hz}, 1 \mathrm{H}), 6.84(\mathrm{~d}, J=8.8 \mathrm{~Hz}, 2 \mathrm{H}), 6.65(\mathrm{~d}, J=8.8 \mathrm{~Hz}, 2 \mathrm{H}), 5.18(\mathrm{~s}, 2 \mathrm{H}) \mathrm{ppm}$; ${ }^{13} \mathrm{C}-\mathrm{NMR}\left(\mathrm{CDCl}_{3}\right): \delta 151.30,141.22,140.89,133.01,132.80,128.45,128.21,117.15,116.37,116.35,111.04$, $68.52 \mathrm{ppm}$.

General Procedure for Synthesis of Intermediates 25d and 26d

$15 \% \mathrm{KOH}(100 \mathrm{~mL})$ was added to a mixture of compounds $25 \mathbf{c}, \mathbf{2 6 c}$ and $\mathrm{EtOH}(25 \mathrm{~mL})$ under $\mathrm{Ar}$ atmosphere, and the mixture was reacted under reflux condition for $36 \mathrm{~h}$. The reaction mixture was washed with EA ( $30 \mathrm{~mL})$, acidified with $1 \mathrm{~N} \mathrm{HCl}$, and extracted with EA. The combined organic layer was washed with saturated $\mathrm{NaCl}$, dried $\left(\mathrm{Na}_{2} \mathrm{SO}_{4}\right)$, concentrated and purified by column chromatography $(\mathrm{DCM} / \mathrm{MeOH}=10: 1, \mathrm{~V} / \mathrm{V}$ ) to give $\mathbf{2 5 d}, \mathbf{2 6 d}$ in yield of about $40 \%$.

2-((4-Aminophenoxy)methyl)benzoic acid (25d): ${ }^{1} \mathrm{H}-\mathrm{NMR}$ (DMSO- $\left.d_{6}\right): \delta 10.62(\mathrm{~s}, 3 \mathrm{H}), 7.94(\mathrm{~d}, J=7.6 \mathrm{~Hz}$, $1 \mathrm{H}), 7.66-7.56(\mathrm{~m}, 2 \mathrm{H}), 7.48-7.43(\mathrm{~m}, 1 \mathrm{H}), 7.33(\mathrm{~d}, J=8.8 \mathrm{~Hz}, 2 \mathrm{H}), 7.08(\mathrm{~d}, J=8.8 \mathrm{~Hz}, 2 \mathrm{H}), 5.47(\mathrm{~s}$, 2H) ppm; ${ }^{13}$ C-NMR (DMSO- $\left.d_{6}\right): \delta 168.05,157.67,137.86,132.09,130.47,129.53,127.96,127.77,124.64$, $124.38,115.60,67.91 \mathrm{ppm}$.

Synthesis of Intermediate IM

4-Aminobenzoic acid (5 mmol) was slowly added to a solution of TCDI (6 mmol) and TEA $(5.5 \mathrm{mmol})$ in DCM $(7.5 \mathrm{~mL})$ at $0{ }^{\circ} \mathrm{C}$. The mixture was stirred for $2 \mathrm{~h}$ at $0{ }^{\circ} \mathrm{C}$ and then added dropwise to $4 \mathrm{M}$ aqueous $\mathrm{HCl}(9 \mathrm{~mL})$. The precipitation was filtered and washed with $1 \mathrm{M}$ aqueous $\mathrm{HCl}(1 \mathrm{~mL} \times 2)$. The resulting sold was dried to afford 4-isothiocyanatobenzoic acid in yield of $90 \%$. Methyl 2-cyanoacetate ( $2 \mathrm{mmol}$ ) followed by a solution of 4-isothiocyanatobenzoic acid $(2 \mathrm{mmol})$ in anhydrous DMF $(2 \mathrm{~mL})$ were added to a cold suspension of powdered $\mathrm{KOH}(4 \mathrm{mmol})$ in dry DMF $(2 \mathrm{~mL})$. The mixture was stirred at room temperature for $0.5 \mathrm{~h}$, then cooled again to $0{ }^{\circ} \mathrm{C}$, treated with a solution of 2-chloroacetyl chloride $(3 \mathrm{mmol})$ in anhydrous DMF $(2 \mathrm{~mL})$ and stirred at room temperature overnight. The mixture was poured into ice-cold water, and the resulting precipitate was filtered off, dried, and crystallized from DCM-EtOH to give intermediate IM in yield of $68 \%$. Mp 290.1-290.7 ${ }^{\circ} \mathrm{C} .{ }^{1} \mathrm{H}-\mathrm{NMR}\left(\mathrm{DMSO}-d_{6}\right): \delta$ $13.28(\mathrm{~s}, 1 \mathrm{H}), 8.06(\mathrm{~d}, J=8.4 \mathrm{~Hz}, 2 \mathrm{H}), 7.56(\mathrm{~d}, J=8.4 \mathrm{~Hz}, 2 \mathrm{H}), 4.08(\mathrm{~s}, 2 \mathrm{H}), 3.71(\mathrm{~s}, 3 \mathrm{H}) \mathrm{ppm} .{ }^{13} \mathrm{C}-\mathrm{NMR}$ (DMSO- $d_{6}$ ): $\delta 173.30,172.30,166.57,165.31,138.53,132.45,130.22,129.71,112.32,75.76,52.38,32.27$ ppm. HRMS (EI) calc. for $\mathrm{C}_{12} \mathrm{H}_{8} \mathrm{~N}_{2} \mathrm{O}_{3} \mathrm{~S}^{+} 318.0310$; found 318.0312.

General Procedure for the Synthesis of Intermediates $40 \mathrm{~b}$ and $41 \mathrm{~b}$

TEA ( $15 \mathrm{mmol})$ followed by 4-nitrobenzoyl chloride $(10 \mathrm{mmol})$ was dropwise added to a solution of compound 40a, 41a in THF ( $40 \mathrm{~mL}$ ) in ice bath. The mixture was allowed to stir at room temperature overnight. Then the mixture was diluted with water $(50 \mathrm{~mL})$, acidified with $1 \mathrm{M} \mathrm{HCl}$, filtered. The filter cake was washed with water, crystallized from $\mathrm{DCM}-\mathrm{MeOH}$ to give intermediate $\mathbf{4 0 b}, \mathbf{4 1 \mathbf { b }}$.

3-(4-Nitrobenzamido)benzoic acid (41b): ${ }^{1} \mathrm{H}-\mathrm{NMR}\left(\mathrm{DMSO}_{6}\right)$ ) $\delta 10.80(\mathrm{~s}, 1 \mathrm{H}), 8.43(\mathrm{~s}, 1 \mathrm{H}), 8.23(\mathrm{~d}$, $J=8.8 \mathrm{~Hz}, 2 \mathrm{H}), 8.23(\mathrm{~d}, J=8.8 \mathrm{~Hz}, 2 \mathrm{H}), 8.06(\mathrm{~d}, J=8.0 \mathrm{~Hz}, 1 \mathrm{H}), 7.73(\mathrm{~d}, J=8.0 \mathrm{~Hz}, 1 \mathrm{H}), 7.52(\mathrm{t}, J=8.0 \mathrm{~Hz}$, 
1H) ppm; ${ }^{13}$ C-NMR (DMSO- $\left.d_{6}\right): \delta 167.08,164.04,149.19,140.22,138.91,131.25,129.25,128.98,124.92$, $124.52,123.53,121.21 \mathrm{ppm}$.

General Procedure for the Synthesis of Intermediates 40c and 41c

Compounds $40 \mathrm{c}$ and $41 \mathrm{c}$ were prepared from $40 \mathrm{~b}$ and $41 \mathrm{~b}$ according the same procedure described for $19 \mathrm{c}-22 \mathrm{c}$.

Synthesis of Intermediate $42 a$

Phthalide $(10 \mathrm{mmol})$ and potassium phthalimide $(11 \mathrm{mmol})$ was added to DMF $(7 \mathrm{~mL})$. The mixture was stirred under reflux condition until the reaction was completed. $35 \% \mathrm{AcOH}(11 \mathrm{~mL})$ was added after cooling to room temperature. The resulted mixture was filtered after stirring for $0.5 \mathrm{~h}$. The filter cake was washed with water and $\mathrm{EtOH}$ in order, crystallized from $\mathrm{DCM}-\mathrm{MeOH}$ to give intermediate 42a in yield of 56\%.

Synthesis of Intermediate $\mathbf{4 2 b}$

Compound 42a $(5 \mathrm{mmol})$ was dissolved in DMF $(10 \mathrm{~mL})$ and EtOH $(20 \mathrm{~mL})$. The mixture was heated to $75{ }^{\circ} \mathrm{C}$, added $80 \%$ hydrazine hydrate $(0.6 \mathrm{~mL})$ and stirred at this temperature overnight. The mixture was filtered after cooling to room temperature. The filtrate was concentrated to give $\mathbf{4 2 b}$ in yield of $80 \%$.

Synthesis of Intermediate 43a

Concentrated $\mathrm{H}_{2} \mathrm{SO}_{4}(30 \mathrm{mmol})$ was added to a mixture of magnesium sulfate $(120 \mathrm{mmol})$ and DCM $(120 \mathrm{~mL})$. Then 3-cyanobenzoic acid $(30 \mathrm{mmol})$ and tert-butanol were added after stirring for $15 \mathrm{~min}$. The mixture was stirred at room temperature for $24 \mathrm{~h}$ and filtered. The filtrate was neutralized with saturated $\mathrm{NaHCO}_{3}$, diluted with water, and extracted with DCM. The combined organic layer was washed with saturated $\mathrm{NaCl}$, concentrated and purified by column chromatography (PE/EA=3:1, $\mathrm{V} / \mathrm{V})$ to give $43 \mathrm{a}$ in yield of $58 \% .{ }^{1} \mathrm{H}-\mathrm{NMR}\left(\mathrm{DMSO}^{-} \mathrm{d}_{6}\right): \delta 8.25(\mathrm{~s}, 1 \mathrm{H}), 8.19(\mathrm{~d}, J=8.0 \mathrm{~Hz}, 1 \mathrm{H}), 8.10(\mathrm{~d}$, $J=8.0 \mathrm{~Hz}, 1 \mathrm{H}), 7.72(\mathrm{t}, J=8.0 \mathrm{~Hz}, 1 \mathrm{H}), 1.56(\mathrm{~s}, 9 \mathrm{H}) \mathrm{ppm} .{ }^{13} \mathrm{C}-\mathrm{NMR}\left(\mathrm{DMSO}-d_{6}\right): \delta 163.21,136.23,133.41$, $132.47,132.40,130.04,117.97,111.91,81.87,27.62 \mathrm{ppm}$.

Synthesis of Intermediate $\mathbf{4 3 b}$

A mixture of $\mathrm{HCOOH}$ and TEA $(25 \mathrm{~mL}, \mathrm{~V}: \mathrm{V}=5: 1)$ followed by Pd/C $(1.1 \mathrm{~g})$ was slowly added to a solution of compound 43a in THF $(25 \mathrm{~mL})$ under Ar atmosphere. The mixture was stirred at $40^{\circ} \mathrm{C}$ for $4 \mathrm{~h}$ and filtered. The filtrate was neutralized with saturated $\mathrm{NaHCO}_{3}$ and concentrated to remove THF. The residue was extracted with EA. The combined organic layer was washed with saturated $\mathrm{NaCl}$, dried $\left(\mathrm{Na}_{2} \mathrm{SO}_{4}\right)$, and concentrated to give compound 43b. GC-MS $\mathrm{m} / \mathrm{z} 207[\mathrm{M}]^{+}$.

Synthesis of Intermediate $43 \mathrm{c}$

Compound 43b (2 mmol), IM (2 mmol), and 4-dimethylaminopyridine (DMAP, $20 \mathrm{mg}$ ) was added to DCM (20 mL). Then 1-ethyl-(3-dimethylaminopropyl)carbonyldiimide hydrochloride (EDCI, $4 \mathrm{mmol}$ ) was added. The mixture was stirred at room temperature until the reaction was completed, and concentrated. The residue was purified by column chromatography $(\mathrm{PE} / \mathrm{EA}=4: 3, \mathrm{~V} / \mathrm{V})$ to give $43 \mathrm{c}$ in yield of $68 \% .{ }^{1} \mathrm{H}-\mathrm{NMR}\left(\mathrm{DMSO}-d_{6}\right): \delta 9.28(\mathrm{t}, J=6.0 \mathrm{~Hz}, 1 \mathrm{H}), 8.02(\mathrm{~d}, J=8.8 \mathrm{~Hz}, 2 \mathrm{H}), 7.89(\mathrm{~s}, 1 \mathrm{H})$, $7.79(\mathrm{~d}, J=7.6 \mathrm{~Hz}, 1 \mathrm{H}), 7.60(\mathrm{~d}, J=8.0 \mathrm{~Hz}, 1 \mathrm{H}), 7.54(\mathrm{~d}, J=8.8 \mathrm{~Hz}, 2 \mathrm{H}), 7.48(\mathrm{~d}, J=8.0 \mathrm{~Hz}, 1 \mathrm{H}), 4.55(\mathrm{~d}$, $J=6.0 \mathrm{~Hz}, 2 \mathrm{H}), 4.09(\mathrm{~s}, 2 \mathrm{H}), 3.71(\mathrm{~s}, 3 \mathrm{H}), 1.54(\mathrm{~s}, 9 \mathrm{H}) \mathrm{ppm}$.

\section{Synthesis of Intermediate 44a}

$\mathrm{KMnO}_{4}(60 \mathrm{mmol})$ was added to a solution of 1-(tert-butyl)-2-methylbenzene in tert-butanol $(60 \mathrm{~mL})$ and water $(60 \mathrm{~mL})$. The mixture was stirred under reflux condition until the reaction was 
completed and filtered. The filtrate was concentrated to remove tert-butanol, acidified with concentrated $\mathrm{HCl}$, and filtered. The filter cake was dried to give 44a, which was directly used in the next step.

Synthesis of Intermediate $\mathbf{4 4 b}$

Compound $44 \mathbf{b}$ was dissolved in concentrated $\mathrm{H}_{2} \mathrm{SO}_{4}(25 \mathrm{~mL})$ and cooled to $0{ }^{\circ} \mathrm{C}$. Then a solution of $\mathrm{KNO}_{3}(20 \mathrm{mmol})$ in concentrated $\mathrm{H}_{2} \mathrm{SO}_{4}(25 \mathrm{~mL})$ was dropwise added to the mixture. The mixture was reacted at $0{ }^{\circ} \mathrm{C}$ until the reaction was completed, and dropwise added to ice water. The resulted mixture was filtered and washed with water. The filter cake was dried and crystallized from EtOH to give intermediate $44 \mathrm{~b}$ in yield of $40 \%$ over two steps. ${ }^{1} \mathrm{H}-\mathrm{NMR}$ (DMSO- $\left.d_{6}\right): \delta 13.75(\mathrm{~s}, 1 \mathrm{H}), 8.21$ $(\mathrm{dd}, J=8.8,2.8 \mathrm{~Hz}, 1 \mathrm{H}), 8.10(\mathrm{~d}, J=2.8 \mathrm{~Hz}, 1 \mathrm{H}), 7.80(\mathrm{~d}, J=8.8 \mathrm{~Hz}, 1 \mathrm{H}), 1.43(\mathrm{~s}, 9 \mathrm{H}) \mathrm{ppm} ;{ }^{13} \mathrm{C}-\mathrm{NMR}$ (DMSO- $d_{6}$ ): $\delta 170.88,153.99,144.99,135.54,128.88,123.82,122.76,36.35,30.62$ ppm.

Synthesis of Intermediate $44 \mathrm{c}$

Compound $44 \mathrm{~b}(10 \mathrm{mmol})$ was added to a mixture of $\mathrm{EtOH}(60 \mathrm{~mL})$ and water $(15 \mathrm{~mL})$. Then reduced iron powder (100 mmol) and concentrated $\mathrm{HCl}(10$ drops) were added. The mixture was stirred under reflux condition until the reaction was completed, filtered. The filter cake was washed with EA. The filtrate was concentrated and directly used in the next step.

Synthesis of Intermediate $44 \mathrm{~d}$

4-Nitrobenzoyl chloride (6 mmol) was slowly added to a mixture of compound 44c, DCM (30 mL), and TEA $(10 \mathrm{mmol})$. The obtained mixture was stirred at room temperature until the reaction was completed. The mixture was acidified with $1 \mathrm{M} \mathrm{HCl}$ and filtered. The filter cake was washed with water, dried and crystallized from $\mathrm{DCM} / \mathrm{MeOH}$ to give intermediate $44 \mathrm{~d}$ in yield of $40 \%$ over two steps. ${ }^{1} \mathrm{H}-\mathrm{NMR}$ (DMSO- $\left.d_{6}\right): \delta 13.15(\mathrm{~s}, 1 \mathrm{H}), 10.61(\mathrm{~s}, 1 \mathrm{H}), 8.42-8.35(\mathrm{~m}, 2 \mathrm{H}), 8.23-8.17(\mathrm{~m}, 2 \mathrm{H}), 7.81-7.76(\mathrm{~m}$, $2 \mathrm{H}), 7.49(\mathrm{~d}, J=9.2 \mathrm{~Hz}, 1 \mathrm{H}), 1.39(\mathrm{~s}, 9 \mathrm{H}) \mathrm{ppm} ;{ }^{13} \mathrm{C}-\mathrm{NMR}\left(\mathrm{DMSO}-d_{6}\right): \delta 172.65,163.77,149.18,141.93$, $140.26,136.09,134.46,129.16,127.25,123.54,120.89,119.73,35.23,31.10 \mathrm{ppm}$.

\section{Synthesis of Intermediate 44e}

Compound 44e was prepared from $44 \mathrm{~d}$ in the same manner as described for $44 \mathrm{c} .{ }^{1} \mathrm{H}-\mathrm{NMR}$ (DMSO- $\left.d_{6}\right): \delta 13.00(\mathrm{~s}, 1 \mathrm{H}), 9.79(\mathrm{~s}, 1 \mathrm{H}), 7.78-7.66(\mathrm{~m}, 4 \mathrm{H}), 7.45-7.34(\mathrm{~m}, 1 \mathrm{H}), 6.60(\mathrm{~d}, J=8.8 \mathrm{~Hz}, 2 \mathrm{H})$, $5.76(\mathrm{~s}, 2 \mathrm{H}), 1.37$ (s, 9H) ppm; ${ }^{13} \mathrm{C}-\mathrm{NMR}\left(\mathrm{DMSO}_{6}\right): \delta 165.20,152.17,140.36,137.12,129.31,126.83$, $120.79,120.29,119.28,112.50,79.15,35.09,31.18 \mathrm{ppm}$.

Synthesis of Intermediate 45a

2-Bromonaphthalene $(50 \mathrm{mmol}$ ) was dissolved in dry DCM under Ar atmosphere and cooled to $-10{ }^{\circ} \mathrm{C}$. Then the mixture was added $\mathrm{AlCl}_{3}(150 \mathrm{mmol})$ and stirred until it turns green. Then acetyl chloride was added after cooling to $-78^{\circ} \mathrm{C}$ and stirred at this temperature for $3 \mathrm{~h}$. The mixture was quenched with $1 \mathrm{M} \mathrm{HCl}$, diluted with water, and extracted with DCM. The combined organic phases were washed with $1 \mathrm{M} \mathrm{HCl}$ and saturated $\mathrm{NaCl}$ in order, dried over $\mathrm{Na}_{2} \mathrm{SO}_{4}$, and the solvent was removed under reduced pressure. The residue was purified by column chromatography ( $\mathrm{PE} / \mathrm{EA}=4: 1$, $\mathrm{V} / \mathrm{V})$ to give $45 \mathrm{~d}$ in yield of $89 \% .{ }^{1} \mathrm{H}-\mathrm{NMR}\left(\mathrm{CDCl}_{3}\right): \delta 9.03(\mathrm{~d}, J=2.0 \mathrm{~Hz}, 1 \mathrm{H}), 7.99(\mathrm{dd}, J=7.2,1.0 \mathrm{~Hz}$, $1 \mathrm{H}), 7.96(\mathrm{~d}, J=8.4 \mathrm{~Hz}, 1 \mathrm{H}), 7.73(\mathrm{~d}, J=8.8 \mathrm{~Hz}, 1 \mathrm{H}), 7.62(\mathrm{dd}, J=8.8,2.0 \mathrm{~Hz}, 1 \mathrm{H}), 7.52(\mathrm{dd}, J=8.4$, $7.2 \mathrm{~Hz}, 1 \mathrm{H}), 2.74(\mathrm{~s}, 3 \mathrm{H}) \mathrm{ppm} ;{ }^{13} \mathrm{C}-\mathrm{NMR}\left(\mathrm{CDCl}_{3}\right): \delta 201.06,134.13,133.08,132.42,131.13,130.04,129.84$, $128.57,124.76,123.01,29.76 \mathrm{ppm}$.

Synthesis of Intermediates $\mathbf{4 5 b}$

Compound 45a (20 mmol), ammonia (100 mmol), $\mathrm{CuI}(4 \mathrm{mmol})$, L-proline $(8 \mathrm{mmol})$, and $\mathrm{K}_{2} \mathrm{CO}_{3}$ $(60 \mathrm{mmol})$ was suspended in DMSO $(40 \mathrm{~mL})$ under Ar atmosphere. The mixture was stirred at $85^{\circ} \mathrm{C}$ for $24 \mathrm{~h}$, and filtered after cooling to room temperature. The filter cake was washed with EA. The 
filtrate was diluted with water and extracted with EA. The combined organic phases were washed with saturated $\mathrm{NaCl}$, dried over $\mathrm{Na}_{2} \mathrm{SO}_{4}$, and the solvent was removed under reduced pressure. The residue was purified by column chromatography ( $\mathrm{PE} / \mathrm{EA}=3: 1, \mathrm{~V} / \mathrm{V})$ to give $45 \mathrm{~b}$ in yield of $52 \%$.

Synthesis of Intermediates 46a

DMAP $(0.5 \mathrm{mmol})$ and tert-butyl carbazate $(6 \mathrm{mmol})$ were added to a mixture of compound IM and DCM $(25 \mathrm{~mL})$. Then the mixture was added EDCI $(10 \mathrm{mmol})$ and stirred at room temperature until the reaction was completed. The solvent was removed under reduced pressure and the residue was purified by column chromatography (DCM/acetone $=10: 1, \mathrm{~V} / \mathrm{V}$ ) to give $46 \mathrm{a}$ in yield of $72 \% .{ }^{1} \mathrm{H}$ - NMR $\left(\mathrm{CDCl}_{3}\right): \delta 8.79(\mathrm{~s}, 1 \mathrm{H}), 7.94(\mathrm{~d}, J=8.4 \mathrm{~Hz}, 2 \mathrm{H}), 7.31(\mathrm{~d}, J=8.4 \mathrm{~Hz}, 2 \mathrm{H}), 6.86(\mathrm{~s}, 1 \mathrm{H}), 3.91(\mathrm{~s}, 2 \mathrm{H}), 3.81(\mathrm{~s}$, $3 \mathrm{H}), 1.50(\mathrm{~s}, 9 \mathrm{H}) \mathrm{ppm} ;{ }^{13} \mathrm{C}-\mathrm{NMR}\left(\mathrm{CDCl}_{3}\right): \delta 172.20,170.07,165.67,165.62,155.69,137.12,129.25,129.15$, $111.85,81.99,78.88,52.90,31.79,28.34,28.18 \mathrm{ppm}$.

Synthesis of Intermediate $\mathbf{4 6 b}$

$\mathrm{CF}_{3} \mathrm{COOH}$ was added to a solution of compound 46a in DCM $(45 \mathrm{~mL})$. The mixture was stirred at room temperature overnight and concentrated to give $\mathbf{4 6 b}$, which was directly used in the next step.

Synthesis of Aryl Isothiocyanates 9e-22e, 23c, 24d

A mixture of 1,4-diazabicyclo(2.2.2) octane (DABCO, $15 \mathrm{mmol}$ ), aromatic amines $\mathbf{9 c}-\mathbf{2 2 c}, \mathbf{2 3 a}, \mathbf{2 4 b}$ $(5 \mathrm{mmol})$, and carbon disulfide $(25 \mathrm{~mL})$ in acetone $(5 \mathrm{~mL})$ was stirred overnight at room temperature. The precipitated solid was filtered. To a mixture of the solid and chloroform $(20 \mathrm{~mL})$ at $0{ }^{\circ} \mathrm{C}$, was added dropwise a solution of triphosgene $(2 \mathrm{mmol})$ in chloroform $(10 \mathrm{~mL})$ over $30 \mathrm{~min}$. The reaction mixture was allowed to warm to room temperature and stirred overnight. After the resulting mixture was filtered, the filtrate was concentrated under reduced pressure and purified by column chromatography (100\% PE) to give $\mathbf{9 c}-\mathbf{2 2 c}, \mathbf{2 3 a}, \mathbf{2 4 b}$ in $70 \%-95 \%$ yield as white solids or colorless oils.

Synthesis of Aryl Isothiocyanates 25e, 26e, 40d, 41d, 44f

Isothiocyanates $25 \mathrm{e}, \mathbf{2 6 e}, \mathbf{4 0 d}, \mathbf{4 1 d}$ and $44 \mathrm{f}$ were prepared from $\mathbf{2 5 d}, \mathbf{2 6 d}, \mathbf{4 0 c}, 41 \mathrm{c}$, 44e in the same manner as described for 4-isothiocyanatobenzoic acid.

\subsubsection{Synthesis of Compounds $\mathbf{9 - 2 6 , 4 0 , 4 1 , 4 4}$}

Compounds 9-26, 40, 41 and 44 were prepared from 9e-22e, 23c, 24d, 25e, 26e, 40d, 41d, 44f in the same manner as described for compound IM.

Methyl (Z)-2-(3-([1,1'-biphenyl]-4-yl)-4-oxothiazolidin-2-ylidene)-2-cyanoacetate (9). Mp 235.1-235.5 ${ }^{\circ} \mathrm{C}$. ${ }^{1} \mathrm{H}-\mathrm{NMR}\left(\mathrm{DMSO}-\mathrm{d}_{6}\right): \delta 7.82(\mathrm{~d}, J=8.4 \mathrm{~Hz}, 2 \mathrm{H}), 7.75(\mathrm{~d}, J=7.2 \mathrm{~Hz}, 2 \mathrm{H}), 7.51(\mathrm{t}, J=8.0 \mathrm{~Hz}, 4 \mathrm{H}), 7.43(\mathrm{t}$, $J=7.2 \mathrm{~Hz}, 1 \mathrm{H}), 4.10(\mathrm{~s}, 2 \mathrm{H}), 3.72(\mathrm{~s}, 3 \mathrm{H}) \mathrm{ppm}$. HRMS (ES+) calcd for $\mathrm{C}_{19} \mathrm{H}_{14} \mathrm{~N}_{2} \mathrm{O}_{3} \mathrm{~S}(\mathrm{M}+\mathrm{H})^{+}, 351.0803$; found, 351.0802 .

Methyl (Z)-2-cyano-2-(3-(3-fluoro-[1,1'-biphenyl]-4-yl)-4-oxothiazolidin-2-ylidene)acetate (10). Mp 180.0-180.1 ${ }^{\circ} \mathrm{C} .{ }^{1} \mathrm{H}-\mathrm{NMR}\left(\mathrm{DMSO}-d_{6}\right): \delta 7.83-7.79(\mathrm{~m}, 3 \mathrm{H}), 7.72\left(\mathrm{dd}, J_{1}=8.4 \mathrm{~Hz}, J_{2}=2.0 \mathrm{~Hz}, 1 \mathrm{H}\right)$, $7.66(\mathrm{t}, J=7.6 \mathrm{~Hz}, 1 \mathrm{H}), 7.56-7.43(\mathrm{~m}, 3 \mathrm{H}), 4.24\left(\mathrm{ABq}, J_{\text {gem }}=18.8 \mathrm{~Hz}, 2 \mathrm{H}\right), 3.74(\mathrm{~s}, 3 \mathrm{H}) \mathrm{ppm} .{ }^{19} \mathrm{~F}-\mathrm{NMR}$ (DMSO- $\left.d_{6}\right): \delta-121.94(\mathrm{t}, J=9.4 \mathrm{~Hz})$ ppm. HRMS $(\mathrm{ES}+)$ calcd for $\mathrm{C}_{19} \mathrm{H}_{13} \mathrm{FN}_{2} \mathrm{O}_{3} \mathrm{~S}(\mathrm{M}+\mathrm{H})^{+}, 369.0703$; found, 369.0709 .

Methyl (Z)-2-cyano-2-(3-(3,5-difluoro-[1,1'-biphenyl]-4-yl)-4-oxothiazolidin-2-ylidene)acetate (11). Mp 185.6-186.0 ${ }^{\circ} \mathrm{C} .{ }^{1} \mathrm{H}-\mathrm{NMR}$ (DMSO- $\left.d_{6}\right): \delta 7.82\left(\mathrm{dd}, J_{1}=16.8 \mathrm{~Hz}, J_{2}=6.8 \mathrm{~Hz}, 4 \mathrm{H}\right), 7.55-7.47(\mathrm{~m}$, $3 \mathrm{H}), 4.40(\mathrm{~s}, 2 \mathrm{H}), 3.76(\mathrm{~s}, 3 \mathrm{H}) \mathrm{ppm} .{ }^{19} \mathrm{~F}-\mathrm{NMR}\left(\mathrm{DMSO}-d_{6}\right): \delta-118.44(\mathrm{~d}, J=11.1 \mathrm{~Hz})$ ppm. HRMS (ES+) calcd for $\mathrm{C}_{19} \mathrm{H}_{12} \mathrm{~F}_{2} \mathrm{~N}_{2} \mathrm{O}_{3} \mathrm{~S}(\mathrm{M}+\mathrm{H})^{+}, 387.0615$; found, 387.0621 .

Methyl (Z)-2-cyano-2-(3-(3-fluoro-2'-methyl-[1,1'-biphenyl]-4-yl)-4-oxothiazolidin-2-ylidene)acetate (12). Mp 198.6-198.9 ${ }^{\circ} \mathrm{C} .{ }^{1} \mathrm{H}-\mathrm{NMR}\left(400 \mathrm{MHz}, \mathrm{DMSO}-d_{6}\right): \delta 7.63(\mathrm{t}, J=8.0 \mathrm{~Hz}, 1 \mathrm{H}), 7.44(\mathrm{~d}, J=10.8 \mathrm{~Hz}, 1 \mathrm{H})$, 
7.33-7.26 (m, 5H), $4.25\left(\mathrm{ABq}, J_{\text {gem }}=18.8 \mathrm{~Hz}, 2 \mathrm{H}\right), 3.75(\mathrm{~s}, 3 \mathrm{H}), 2.26(\mathrm{~s}, 3 \mathrm{H}) \mathrm{ppm} .{ }^{19} \mathrm{~F} \mathrm{NMR}(376 \mathrm{MHz}$, DMSO- $\left.d_{6}\right): \delta-122.72(\mathrm{t}, J=9.4 \mathrm{~Hz})$ ppm. HRMS $(\mathrm{ES}+)$ calcd for $\mathrm{C}_{20} \mathrm{H}_{15} \mathrm{FN}_{2} \mathrm{O}_{3} \mathrm{~S}(\mathrm{M}+\mathrm{H})^{+}, 383.0866$; found, 383.0868 .

Methyl (Z)-2-cyano-2-(3-(3-fluoro-2'-methoxy-[1,1'-biphenyl]-4-yl)-4-oxothiazolidin-2-ylidene)acetate (13). Mp 220.1-220.5 ${ }^{\circ} \mathrm{C} .{ }^{1} \mathrm{H}-\mathrm{NMR}\left(\mathrm{DMSO}-d_{6}\right): \delta 7.59(\mathrm{t}, J=8.0 \mathrm{~Hz}, 2 \mathrm{H}), 7.50\left(\mathrm{dd}, J_{1}=8.4 \mathrm{~Hz}, J_{2}=1.6 \mathrm{~Hz}, 1 \mathrm{H}\right)$, $7.43\left(\mathrm{td}, J_{1}=8.0 \mathrm{~Hz}, J_{2}=1.6 \mathrm{~Hz}, 1 \mathrm{H}\right), 7.37\left(\mathrm{dd}, J_{1}=7.2 \mathrm{~Hz}, J_{2}=1.6 \mathrm{~Hz}, 1 \mathrm{H}\right), 7.18(\mathrm{~d}, J=8.0 \mathrm{~Hz}, 1 \mathrm{H}), 7.08$ $(\mathrm{t}, J=7.4 \mathrm{~Hz}, 1 \mathrm{H}), 4.24\left(\mathrm{ABq}, J_{\text {gem }}=18.8 \mathrm{~Hz}, 2 \mathrm{H}\right), 3.82(\mathrm{~s}, 3 \mathrm{H}), 3.75(\mathrm{~s}, 3 \mathrm{H}) \mathrm{ppm} .{ }^{19} \mathrm{~F}-\mathrm{NMR}\left(\mathrm{DMSO}-d_{6}\right): \delta$ $-123.08\left(\mathrm{dd}, J_{1}=12.8 \mathrm{~Hz}, J_{2}=8.5 \mathrm{~Hz}\right) \mathrm{ppm}$. HRMS $(\mathrm{ES}+)$ calcd for $\mathrm{C}_{20} \mathrm{H}_{15} \mathrm{FN}_{2} \mathrm{O}_{4} \mathrm{~S}(\mathrm{M}+\mathrm{H})^{+}, 399.0815$; found, 399.0814 .

Methyl (Z)-2-cyano-2-(3-(3-fluoro-3'-methoxy-[1,1'-biphenyl]-4-yl)-4-oxothiazolidin-2-ylidene)acetate (14). Mp 193.1-193.6 ${ }^{\circ} \mathrm{C} .{ }^{1} \mathrm{H}-\mathrm{NMR}\left(\mathrm{DMSO}-\mathrm{d}_{6}\right): \delta 7.84\left(\mathrm{dd}, J_{1}=11.6 \mathrm{~Hz}, J_{2}=1.6 \mathrm{~Hz}, 1 \mathrm{H}\right), 7.73\left(\mathrm{dd}, J_{1}=8.4 \mathrm{~Hz}\right.$, $\left.J_{2}=1.6 \mathrm{~Hz}, 1 \mathrm{H}\right), 7.65(\mathrm{t}, J=8.0 \mathrm{~Hz}, 1 \mathrm{H}), 7.43(\mathrm{t}, J=8.0 \mathrm{~Hz}, 1 \mathrm{H}), 7.35(\mathrm{t}, J=8.0 \mathrm{~Hz}, 2 \mathrm{H}), 7.03(\mathrm{dd}$, $\left.J_{1}=8.0 \mathrm{~Hz}, J_{2}=1.6 \mathrm{~Hz}, 1 \mathrm{H}\right), 4.24\left(\mathrm{ABq}, J_{g e m}=18.8 \mathrm{~Hz}, 2 \mathrm{H}\right), 3.86(\mathrm{~s}, 3 \mathrm{H}), 3.75(\mathrm{~s}, 3 \mathrm{H}) \mathrm{ppm} .{ }^{19} \mathrm{~F}-\mathrm{NMR}$ (DMSO- $\left.d_{6}\right): \delta-121.97\left(\mathrm{dd}, J_{1}=12.8 \mathrm{~Hz}, J_{2}=9.4 \mathrm{~Hz}\right)$ ppm. HRMS (ES+) calcd for $\mathrm{C}_{20} \mathrm{H}_{15} \mathrm{FN}_{2} \mathrm{O}_{4} \mathrm{~S}(\mathrm{M}+$ $\mathrm{H})^{+}, 399.0815$; found, 399.0821 .

Methyl (Z)-2-cyano-2-(3-(3-fluoro-4'-methoxy-[1,1'-biphenyl]-4-yl)-4-oxothiazolidin-2-ylidene)acetate (15). Mp 177.1-177.3 ${ }^{\circ} \mathrm{C} .{ }^{1} \mathrm{H}-\mathrm{NMR}\left(\mathrm{DMSO}-\mathrm{d}_{6}\right): \delta 7.77-7.72(\mathrm{~m}, 3 \mathrm{H}), 7.65(\mathrm{~d}, J=8.8 \mathrm{~Hz}, 1 \mathrm{H}), 7.59(\mathrm{t}, J=8.0 \mathrm{~Hz}$, $1 \mathrm{H}), 7.07(\mathrm{~d}, J=8.8 \mathrm{~Hz}, 2 \mathrm{H}), 4.22\left(\mathrm{ABq}, J_{g e m}=18.6 \mathrm{~Hz}, 2 \mathrm{H}\right), 3.83(\mathrm{~s}, 3 \mathrm{H}), 3.74(\mathrm{~s}, 3 \mathrm{H}) \mathrm{ppm} .{ }^{19} \mathrm{~F}-\mathrm{NMR}$ $\left(\right.$ DMSO- $\left.d_{6}\right): \delta-122.12\left(\mathrm{dd}, J_{1}=13.2 \mathrm{~Hz}, J_{2}=8.9 \mathrm{~Hz}\right) \mathrm{ppm}$. HRMS (ES+) calcd for $\mathrm{C}_{20} \mathrm{H}_{15} \mathrm{FN}_{2} \mathrm{O}_{4} \mathrm{~S}(\mathrm{M}+$ $\mathrm{H})^{+}, 399.0815$; found, 399.0816 .

Methyl (Z)-2-cyano-2-(3-(3'-cyano-3-fluoro-[1,1'-biphenyl]-4-yl)-4-oxothiazolidin-2-ylidene)acetate (16). Mp 191.2-191.3 ${ }^{\circ} \mathrm{C} .{ }^{1} \mathrm{H}-\mathrm{NMR}\left(\mathrm{DMSO}-d_{6}\right): \delta 8.33(\mathrm{~s}, 1 \mathrm{H}), 8.16(\mathrm{~d}, J=8.0 \mathrm{~Hz}, 1 \mathrm{H}), 7.95\left(\mathrm{dd}, J_{1}=11.2 \mathrm{~Hz}\right.$, $\left.J_{2}=7.6 \mathrm{~Hz}, 2 \mathrm{H}\right), 7.83(\mathrm{~d}, J=8.4 \mathrm{~Hz}, 1 \mathrm{H}), 7.72(\mathrm{q}, J=7.6 \mathrm{~Hz}, 2 \mathrm{H}), 4.24\left(\mathrm{ABq}, J_{\text {gem }}=18.8 \mathrm{~Hz}, 2 \mathrm{H}\right), 3.75(\mathrm{~s}$, $3 \mathrm{H})$ ppm. ${ }^{19} \mathrm{~F}-\mathrm{NMR}\left(\mathrm{DMSO}-d_{6}\right): \delta-121.44\left(\mathrm{td}, J_{1}=8.9 \mathrm{~Hz}, J_{2}=3.4 \mathrm{~Hz}\right) \mathrm{ppm}$. HRMS (ES+) calcd for $\mathrm{C}_{20} \mathrm{H}_{12} \mathrm{FN}_{3} \mathrm{O}_{3} \mathrm{~S}(\mathrm{M}+\mathrm{H})^{+}$, 394.0662; found, 394.0668 .

Methyl (Z)-2-cyano-2-(3-(3-fluoro-3'-nitro-[1,1'-biphenyl]-4-yl)-4-oxothiazolidin-2-ylidene) acetate (17). Mp 179.2-179. $9^{\circ} \mathrm{C} .{ }^{1} \mathrm{H}-\mathrm{NMR}\left(\mathrm{DMSO}-d_{6}\right): \delta 8.57-8.56(\mathrm{~m}, 1 \mathrm{H}), 8.32-8.26(\mathrm{~m}, 2 \mathrm{H}), 8.02\left(\mathrm{dd}, J_{1}=11.2 \mathrm{~Hz}\right.$, $\left.J_{2}=2.0 \mathrm{~Hz}, 1 \mathrm{H}\right), 7.88-7.80(\mathrm{~m}, 2 \mathrm{H}), 7.74(\mathrm{t}, J=8.0 \mathrm{~Hz}, 1 \mathrm{H}), 4.24\left(\mathrm{ABq}, J_{\text {gem }}=18.4 \mathrm{~Hz}, 2 \mathrm{H}\right), 3.75(\mathrm{~s}$, $3 \mathrm{H}) .{ }^{19} \mathrm{~F}-\mathrm{NMR}\left(\mathrm{DMSO}-d_{6}\right): \delta-121.31(\mathrm{t}, J=10.6 \mathrm{~Hz})$. HRMS (ES+) calcd for $\mathrm{C}_{19} \mathrm{H}_{12} \mathrm{FN}_{3} \mathrm{O}_{5} \mathrm{~S}(\mathrm{M}+\mathrm{H})^{+}$, 413.3851; found, 413.3853 .

Methyl (Z)-2-cyano-2-(3-(3-fluoro-3'-(trifluoromethyl)-[1,1'-biphenyl]-4-yl)-4-oxothiazolidin-2-ylidene) -acetate (18). Mp 182.4-183.1 ${ }^{\circ} \mathrm{C} .{ }^{1} \mathrm{H}-\mathrm{NMR}\left(\mathrm{DMSO}_{6}\right)$ : $\delta 8.12(\mathrm{~s}, 1 \mathrm{H}), 7.98(\mathrm{~d}, J=11.2 \mathrm{~Hz}, 1 \mathrm{H}), 7.83$ (dd, $\left.J_{1}=8.4 \mathrm{~Hz}, J_{2}=3.2 \mathrm{~Hz}, 2 \mathrm{H}\right), 7.78-7.70(\mathrm{~m}, 2 \mathrm{H}), 4.18\left(\mathrm{ABq}, J_{\text {gem }}=18.8 \mathrm{~Hz}, 2 \mathrm{H}\right), 3.75(\mathrm{~s}, 3 \mathrm{H}) \mathrm{ppm}$. ${ }^{19} \mathrm{~F}-\mathrm{NMR}\left(\mathrm{DMSO}-d_{6}\right): \delta-61.03(\mathrm{~s}),-121.55\left(\mathrm{dd}, J_{1}=12.3 \mathrm{~Hz}, J_{2}=8.9 \mathrm{~Hz}\right)$ ppm. HRMS (ES+) calcd for $\mathrm{C}_{20} \mathrm{H}_{12} \mathrm{~F}_{4} \mathrm{~N}_{2} \mathrm{O}_{3} \mathrm{~S}(\mathrm{M}+\mathrm{H})^{+}$, 437.0583; found, 437.0591 .

Methyl (Z)-2-cyano-2-(4-oxo-3-(4-phenoxyphenyl)thiazolidin-2-ylidene)acetate (19). White solid, Yield: 72\%. Mp 167.6-168.3 ${ }^{\circ} \mathrm{C} ;{ }^{1} \mathrm{H}-\mathrm{NMR}$ (DMSO- $\left.d_{6}\right): \delta 7.46-7.42(\mathrm{~m}, 2 \mathrm{H}), 7.39(\mathrm{t}, J=8.0 \mathrm{~Hz}, 2 \mathrm{H}), 7.18-7.12(\mathrm{~m}, 3 \mathrm{H})$, $7.07(\mathrm{~d}, J=8.0 \mathrm{~Hz}, 2 \mathrm{H}), 4.07(\mathrm{~s}, 2 \mathrm{H}), 3.71(\mathrm{~s}, 3 \mathrm{H}) \mathrm{ppm} .{ }^{13} \mathrm{C}-\mathrm{NMR}$ (DMSO- $\left.d_{6}\right): \delta 173.40,173.13,165.44$, $157.97,156.72,131.34,130.08,130.01,123.56,119.73,118.35,112.40,75.73,52.35,32.17$ ppm. HRMS (EI) calc. for $\mathrm{C}_{19} \mathrm{H}_{14} \mathrm{~N}_{2} \mathrm{O}_{4} \mathrm{~S}^{+} 366.0674$; found 366.0675 .

Methyl (Z)-2-cyano-2-(3-(4-(2-methoxyphenoxy)phenyl)-4-oxothiazolidin-2-ylidene)acetate (20). White solid, Yield: 74\%. Mp 181.2-182.1 ${ }^{\circ} \mathrm{C} ;{ }^{1} \mathrm{H}-\mathrm{NMR}\left(\mathrm{DMSO}_{6} \mathrm{~d}_{6}\right): \delta 7.34(\mathrm{~d}, J=8.8 \mathrm{~Hz}, 2 \mathrm{H}), 7.25-7.16(\mathrm{~m}, 2 \mathrm{H})$, $7.05(\mathrm{dd}, J=8.0,1.2 \mathrm{~Hz}, 1 \mathrm{H}), 6.99-6.93(\mathrm{~m}, 3 \mathrm{H}), 4.05(\mathrm{~s}, 2 \mathrm{H}), 3.75(\mathrm{~s}, 3 \mathrm{H}), 3.71(\mathrm{~s}, 3 \mathrm{H}) \mathrm{ppm} .{ }^{13} \mathrm{C}-\mathrm{NMR}$ (DMSO- $d_{6}$ ): $\delta 173.48,173.02,165.48,159.03,151.09,143.57,130.83,128.87,125.66,121.13,121.04,117.08$, $113.45,112.28,75.80,55.61,52.32,32.08$ ppm. HRMS (EI) calc. for $\mathrm{C}_{20} \mathrm{H}_{16} \mathrm{~N}_{2} \mathrm{O}_{5} \mathrm{~S}^{+}$396.0780; found 396.0779 . 
Methyl (Z)-2-cyano-2-(4-oxo-3-(4-(2-(trifluoromethyl)phenoxy)phenyl)thiazolidin-2-ylidene)acetate (21). White solid, Yield: 72\%.Mp 159.7-161.3 ${ }^{\circ} \mathrm{C} ;{ }^{1} \mathrm{H}-\mathrm{NMR}$ (DMSO- $\left.d_{6}\right): \delta 7.61(\mathrm{t}, J=8.2 \mathrm{~Hz}, 1 \mathrm{H}), 7.52$ $(\mathrm{d}, J=8.8 \mathrm{~Hz}, 2 \mathrm{H}), 7.48(\mathrm{~d}, J=8.0 \mathrm{~Hz}, 1 \mathrm{H}), 7.37(\mathrm{~d}, J=6.4 \mathrm{~Hz}, 2 \mathrm{H}), 7.27(\mathrm{~d}, J=8.8 \mathrm{~Hz}, 2 \mathrm{H}), 4.08(\mathrm{~s}, 2 \mathrm{H})$, $3.72(\mathrm{~s}, 3 \mathrm{H}) \mathrm{ppm} .{ }^{13} \mathrm{C}-\mathrm{NMR}\left(\mathrm{DMSO}-d_{6}\right): \delta 173.35,173.07,165.42,157.74,156.76,131.78,131.23,131.16$, $130.77\left(\mathrm{q}^{2} J_{\mathrm{CF}}=31.9 \mathrm{~Hz}\right), 123.65\left(\mathrm{q},{ }^{1} J_{\mathrm{CF}}=270.9 \mathrm{~Hz}\right), 121.75,120.84,119.73\left(\mathrm{q},{ }^{3} J_{\mathrm{CF}}=3.8 \mathrm{~Hz}\right), 114.15(\mathrm{q}$, $\left.{ }^{3} J_{\mathrm{CF}}=3.8 \mathrm{~Hz}\right), 112.42,75.79,52.35,32.20 \mathrm{ppm} .{ }^{19} \mathrm{~F}-\mathrm{NMR}\left(\mathrm{DMSO}-d_{6}\right): \delta-61.13(\mathrm{~s}, 3 \mathrm{~F}) \mathrm{ppm}$. HRMS (EI) calc. for $\mathrm{C}_{20} \mathrm{H}_{13} \mathrm{~F}_{3} \mathrm{~N}_{2} \mathrm{O}_{4} \mathrm{~S}^{+}$434.0548; found 434.0550.

Methyl (Z)-2-(3-(4-(4-(tert-butyl)phenoxy)phenyl)-4-oxothiazolidin-2-ylidene)-2-cyanoacetate (22). White solid, Yield: 74\%. Mp 212.9-213.9 ${ }^{\circ} \mathrm{C} ;{ }^{1} \mathrm{H}-\mathrm{NMR}\left(\mathrm{DMSO}-\mathrm{d}_{6}\right): \delta 7.41(\mathrm{~d}, J=8.4 \mathrm{~Hz}, 2 \mathrm{H}), 7.40(\mathrm{~d}, J=8.4 \mathrm{~Hz}$, $2 \mathrm{H}), 7.11(\mathrm{~d}, J=8.8 \mathrm{~Hz}, 2 \mathrm{H}), 7.00(\mathrm{~d}, J=8.8 \mathrm{~Hz}, 2 \mathrm{H}), 4.07(\mathrm{~s}, 2 \mathrm{H}), 3.71(\mathrm{~s}, 3 \mathrm{H}), 1.28(\mathrm{~s}, 9 \mathrm{H}) \mathrm{ppm} .{ }^{13} \mathrm{C}-\mathrm{NMR}$ (DMSO- $d_{6}$ ): $\delta 173.40,173.11,165.45,158.35,154.28,145.96,131.24,129.81,126.67,119.40,118.05,112.35$, 75.76, 52.34, 34.03, 32.15, 31.21 ppm. HRMS (EI) calc. for $\mathrm{C}_{23} \mathrm{H}_{22} \mathrm{~N}_{2} \mathrm{O}_{4} \mathrm{~S}^{+} 422.1300$; found 422.1299 .

Methyl (Z)-2-cyano-2-(4-oxo-3-(3-phenoxyphenyl)thiazolidin-2-ylidene)acetate (23). White solid, Yield: 76\%. Mp 183.4-184.3 ${ }^{\circ} \mathrm{C} ;{ }^{1} \mathrm{H}-\mathrm{NMR}\left(\mathrm{DMSO}-d_{6}\right): \delta 7.52(\mathrm{t}, J=8.0 \mathrm{~Hz}, 1 \mathrm{H}), 7.39(\mathrm{t}, J=8.0 \mathrm{~Hz}, 2 \mathrm{H}), 7.25-7.20$ $(\mathrm{m}, 2 \mathrm{H}), 7.17-7.12(\mathrm{~m}, 2 \mathrm{H}), 7.10(\mathrm{~d}, J=8.0 \mathrm{~Hz}, 2 \mathrm{H}), 4.01\left(\mathrm{ABq}, J_{\text {gem }}=18.4 \mathrm{~Hz}, 2 \mathrm{H}\right), 3.71(\mathrm{~s}, 3 \mathrm{H}) \mathrm{ppm}$. ${ }^{13}$ C-NMR (DMSO-d $\left.d_{6}\right): \delta$ 173.25, 172.68, 165.40, 157.06, 156.64, 136.07, 130.69, 130.04, 124.60, 123.63, $121.35,119.87,118.48,112.51,75.57,52.36,32.19$ ppm. HRMS (EI) calc. for $\mathrm{C}_{19} \mathrm{H}_{14} \mathrm{~N}_{2} \mathrm{O}_{4} \mathrm{~S}^{+} 366.0674$; found 366.0675 .

Methyl (Z)-2-(3-(4-(benzyloxy)phenyl)-4-oxothiazolidin-2-ylidene)-2-cyanoacetate (24). White solid, Yield: 75\%. Mp 202.0-202.8 ${ }^{\circ} \mathrm{C} ;{ }^{1} \mathrm{H}-\mathrm{NMR}\left(\mathrm{DMSO}-\mathrm{d}_{6}\right): \delta 7.47(\mathrm{~d}, J=7.2 \mathrm{~Hz}, 2 \mathrm{H}), 7.40(\mathrm{t}, J=7.2 \mathrm{~Hz}, 2 \mathrm{H})$, 7.37-7.34 (m, 1H), $7.31(\mathrm{dt}, J=8.8,2.6 \mathrm{~Hz}, 2 \mathrm{H}), 7.11(\mathrm{dt}, J=8.8,2.6 \mathrm{~Hz}, 2 \mathrm{H}), 5.15(\mathrm{~s}, 2 \mathrm{H}), 4.05(\mathrm{~s}, 2 \mathrm{H}), 3.70$ $(\mathrm{s}, 3 \mathrm{H})$ ppm. ${ }^{13} \mathrm{C}-\mathrm{NMR}\left(\mathrm{DMSO}-d_{6}\right): \delta 173.51,173.12,165.51,159.73,136.62,130.54,128.44,127.91,127.74$, $127.48,115.18,112.24,75.74,69.49,52.31,32.00$ ppm. HRMS (EI) calc. for $\mathrm{C}_{20} \mathrm{H}_{16} \mathrm{~N}_{2} \mathrm{O}_{4} \mathrm{~S}^{+} 380.0831$; found 380.0834 .

(Z)-2-((4-(2-(1-Cyano-2-methoxy-2-oxoethylidene)-4-oxothiazolidin-3-yl)phenoxy)methyl)benzoic acid (25). White solid, Yield: 67\%. Mp 210.6-211.5 ${ }^{\circ} \mathrm{C} ;{ }^{1} \mathrm{H}-\mathrm{NMR}\left(\mathrm{DMSO}-\mathrm{d}_{6}\right): \delta 13.13(\mathrm{~s}, 1 \mathrm{H}), 7.95(\mathrm{~d}, J=7.6 \mathrm{~Hz}$, $1 \mathrm{H}), 7.65(\mathrm{~d}, J=7.6 \mathrm{~Hz}, 1 \mathrm{H}), 7.59(\mathrm{t}, J=7.6 \mathrm{~Hz}, 1 \mathrm{H}), 7.46(\mathrm{t}, J=7.6 \mathrm{~Hz}, 1 \mathrm{H}), 7.31(\mathrm{~d}, J=8.8 \mathrm{~Hz}, 2 \mathrm{H}), 7.07$ $(\mathrm{d}, J=8.8 \mathrm{~Hz}, 2 \mathrm{H}), 5.52(\mathrm{~s}, 2 \mathrm{H}), 4.05(\mathrm{~s}, 2 \mathrm{H}), 3.71(\mathrm{~s}, 3 \mathrm{H}) \mathrm{ppm} .{ }^{13} \mathrm{C}-\mathrm{NMR}\left(\mathrm{DMSO}-d_{6}\right): \delta 173.50,173.12$, $168.05,165.50,159.68,137.94,132.17,130.62,130.50,129.27,127.80,127.69,127.57,115.19,112.22,75.78$, $67.88,52.30,32.02$ ppm. HRMS (EI) calc. for $\mathrm{C}_{21} \mathrm{H}_{16} \mathrm{~N}_{2} \mathrm{O}_{6} \mathrm{~S}^{+} 424.0729$; found 424.0728.

(Z)-3-((4-(2-(1-Cyano-2-methoxy-2-oxoethylidene)-4-oxothiazolidin-3-yl)phenoxy)methyl)benzoic acid (26). White solid, Yield: 68\%. Mp 233.2-234.1 ${ }^{\circ} \mathrm{C} ;{ }^{1} \mathrm{H}-\mathrm{NMR}\left(\mathrm{DMSO}-d_{6}\right): \delta 13.02(\mathrm{~s}, 1 \mathrm{H}), 8.06(\mathrm{~s}, 1 \mathrm{H}), 7.92$ $(\mathrm{d}, J=7.6 \mathrm{~Hz}, 1 \mathrm{H}), 7.72(\mathrm{~d}, J=7.6 \mathrm{~Hz}, 1 \mathrm{H}), 7.54(\mathrm{t}, J=7.6 \mathrm{~Hz}, 1 \mathrm{H}), 7.32(\mathrm{~d}, J=8.8 \mathrm{~Hz}, 2 \mathrm{H}), 7.13(\mathrm{~d}$, $J=8.8 \mathrm{~Hz}, 2 \mathrm{H}), 5.24(\mathrm{~s}, 2 \mathrm{H}), 4.05(\mathrm{~s}, 2 \mathrm{H}), 3.71(\mathrm{~s}, 3 \mathrm{H}) \mathrm{ppm} .{ }^{13} \mathrm{C}-\mathrm{NMR}\left(\mathrm{DMSO}-d_{6}\right): \delta 173.48,173.07$, 167.08, 165.50, 159.58, 137.24, 131.97, 130.99, 130.58, 128.78, 128.38, 127.63, 115.23, 112.23, 75.78, 68.94, 52.30, 32.00 ppm. HRMS (EI) calc. for $\mathrm{C}_{21} \mathrm{H}_{16} \mathrm{~N}_{2} \mathrm{O}_{6} \mathrm{~S}^{+} 424.0729$; found 424.0730.

(Z)-2-(4-(2-(1-Cyano-2-methoxy-2-oxoethylidene)-4-oxothiazolidin-3-yl)benzamido)benzoic acid (40). White solid, Yield: 70\%. Mp 261.8-262.5 ${ }^{\circ} \mathrm{C} ;{ }^{1} \mathrm{H}-\mathrm{NMR}\left(\mathrm{DMSO}-d_{6}\right): \delta 13.81(\mathrm{~s}, 1 \mathrm{H}), 12.25(\mathrm{~s}, 1 \mathrm{H}), 8.71(\mathrm{~d}$, $J=8.0 \mathrm{~Hz}, 1 \mathrm{H}), 8.14-8.06(\mathrm{~m}, 3 \mathrm{H}), 7.74-7.63(\mathrm{~m}, 3 \mathrm{H}), 7.24(\mathrm{t}, J=7.4 \mathrm{~Hz}, 1 \mathrm{H}), 4.11(\mathrm{~s}, 2 \mathrm{H}), 3.73(\mathrm{~s}$, $3 \mathrm{H})$ ppm. ${ }^{13} \mathrm{C}-\mathrm{NMR}\left(\mathrm{DMSO}-d_{6}\right): \delta 173.33,172.24,169.94,165.31,162.25,140.80,137.96,136.10,134.28$, 131.26, 130.10, 128.01, 123.20, 120.06, 116.84, 112.36, 75.90, 52.37, 32.25, 30.73 ppm. HRMS (ESI) calc. for $\mathrm{C}_{21} \mathrm{H}_{15} \mathrm{~N}_{3} \mathrm{O}_{6} \mathrm{SNa}^{+}(\mathrm{M}+\mathrm{Na})^{+}, 460.0579$; found 460.0578. HRMS (EI) calc. for $\mathrm{C}_{21} \mathrm{H}_{16} \mathrm{~N}_{2} \mathrm{O}_{6} \mathrm{~S}^{+} 424.0729$; found 424.0728 .

(Z)-3-(4-(2-(1-Cyano-2-methoxy-2-oxoethylidene)-4-oxothiazolidin-3-yl)benzamido)benzoic acid (41). White solid, Yield: 68\%. Mp 205.7-206.6 ${ }^{\circ} \mathrm{C} ;{ }^{1} \mathrm{H}-\mathrm{NMR}\left(\mathrm{DMSO}-d_{6}\right): \delta 12.98(\mathrm{~s}, 1 \mathrm{H}), 10.57(\mathrm{~s}, 1 \mathrm{H}), 8.45(\mathrm{~s}, 1 \mathrm{H})$, $8.13(\mathrm{~d}, J=7.6 \mathrm{~Hz}, 2 \mathrm{H}), 8.07(\mathrm{~d}, J=8.0 \mathrm{~Hz}, 1 \mathrm{H}), 7.71(\mathrm{~d}, J=7.6 \mathrm{~Hz}, 1 \mathrm{H}), 7.61(\mathrm{~d}, J=7.6 \mathrm{~Hz}, 2 \mathrm{H}), 7.50(\mathrm{t}$, $J=7.8 \mathrm{~Hz}, 1 \mathrm{H}), 4.10(\mathrm{~s}, 2 \mathrm{H}), 3.72(\mathrm{~s}, 3 \mathrm{H}) \mathrm{ppm} .{ }^{13} \mathrm{C}-\mathrm{NMR}\left(\mathrm{DMSO}-d_{6}\right): \delta 173.33,172.24,169.94,165.31$, 
162.25, 140.80, 137.96, 136.10, 134.28, 131.26, 130.10, 128.01, 123.20, 120.06, 116.84, 112.36, 75.90, 52.37, 32.25, 30.73 ppm. HRMS (ESI) calc. for $\mathrm{C}_{21} \mathrm{H}_{15} \mathrm{~N}_{3} \mathrm{O}_{6} \mathrm{SNa}^{+}(\mathrm{M}+\mathrm{Na})+, 460.0579$; found 460.0580 .

(Z)-2-(tert-butyl)-5-(4-(2-(1-cyano-2-methoxy-2-oxoethylidene)-4-oxothiazolidin-3-yl)benzamido)benzoic acid (44). White solid, Yield: $69 \%$. Mp 328.1-328.9 ${ }^{\circ} \mathrm{C} ;{ }^{1} \mathrm{H}-\mathrm{NMR}$ (DMSO- $\left.d_{6}\right): \delta 13.13(\mathrm{~s}, 1 \mathrm{H}), 10.44(\mathrm{~s}, 1 \mathrm{H})$, $8.10(\mathrm{~d}, J=8.8 \mathrm{~Hz}, 2 \mathrm{H}), 7.80(\mathrm{dd}, J=8.4,2.4 \mathrm{~Hz}, 1 \mathrm{H}), 7.78(\mathrm{~d}, J=2.4 \mathrm{~Hz}, 1 \mathrm{H}), 7.60(\mathrm{~d}, J=8.8 \mathrm{~Hz}, 2 \mathrm{H}), 7.48$ $(\mathrm{d}, J=8.4 \mathrm{~Hz}, 1 \mathrm{H}), 4.10(\mathrm{~s}, 2 \mathrm{H}), 3.72(\mathrm{~s}, 3 \mathrm{H}), 1.39(\mathrm{~s}, 9 \mathrm{H}) \mathrm{ppm} .{ }^{13} \mathrm{C}-\mathrm{NMR}\left(\mathrm{DMSO}-d_{6}\right): \delta 173.39,172.71$, $172.32,165.35,164.39,141.59,137.55,136.35,136.04,134.42,129.47,128.66,127.19,120.88,119.69,112.38$, $75.79,52.40,35.21,32.23,31.12$ ppm. HRMS (EI) calc. for $\mathrm{C}_{25} \mathrm{H}_{23} \mathrm{~N}_{3} \mathrm{O}_{6} \mathrm{~S}^{+} 493.1308$; found 493.1300 .

\subsubsection{Synthesis of Compounds $27-39,45$}

General procedure for the synthesis of compounds 27-39, 45

Corresponding aromatic amines $(1.2 \mathrm{mmol})$ and DMAP $(0.1 \mathrm{mmol})$ were added to a mixture of compound IM $(1 \mathrm{mmol})$ and DCM $(5 \mathrm{~mL})$. Then the mixture was added EDCI $(2 \mathrm{mmol})$ and stirred at room temperature until the reaction was completed. The solvent was removed under reduced pressure and the residue was purified by column chromatography $(\mathrm{DCM} /$ acetone $=10: 1, \mathrm{~V} / \mathrm{V})$ to give compounds 27-39, 45.

Methyl (Z)-2-cyano-2-(3-(4-(cyclohexylcarbamoyl)phenyl)-4-oxothiazolidin-2-ylidene)acetate (27). White solid, Yield: 78\%. Mp 224.3-225.1 ${ }^{\circ} \mathrm{C}$; ${ }^{1} \mathrm{H}-\mathrm{NMR}\left(\mathrm{DMSO}_{6} \mathrm{~d}_{6}\right): 87.33(\mathrm{~d}, J=8.4 \mathrm{~Hz}, 2 \mathrm{H}), 7.26(\mathrm{~d}, J=8.4 \mathrm{~Hz}$, $2 \mathrm{H}), 4.06(\mathrm{~s}, 2 \mathrm{H}), 3.69(\mathrm{~s}, 3 \mathrm{H}), 2.57(\mathrm{t}, J=9.6 \mathrm{~Hz}, 1 \mathrm{H}), 1.80(\mathrm{~d}, J=9.6 \mathrm{~Hz}, 4 \mathrm{H}), 1.71(\mathrm{~d}, J=12.4 \mathrm{~Hz}, 1 \mathrm{H})$, $1.48-1.31(\mathrm{~m}, 4 \mathrm{H}), 1.30-1.18(\mathrm{~m}, 1 \mathrm{H}) \mathrm{ppm} .{ }^{13} \mathrm{C}-\mathrm{NMR}$ (DMSO- $\left.d_{6}\right): \delta 173.46,172.71,165.50,149.98,132.44$, $128.97,127.46,111.95,75.90,54.87,52.30,43.51,33.80,32.06,26.22,25.52$ ppm. HRMS (EI) calc. for $\mathrm{C}_{20} \mathrm{H}_{21} \mathrm{~N}_{3} \mathrm{O}_{4} \mathrm{~S}^{+}$399.1253; found 399.1251.

Methyl (Z)-2-cyano-2-(4-oxo-3-(4-(phenylcarbamoyl)phenyl)thiazolidin-2-ylidene)acetate (28). White solid, Yield: $48 \%$. Mp 194.9-195.6 ${ }^{\circ} \mathrm{C} ;{ }^{1} \mathrm{H}-\mathrm{NMR}$ (DMSO- $\left.d_{6}\right): \delta 10.40(\mathrm{~s}, 1 \mathrm{H}), 8.11(\mathrm{~d}, J=8.4 \mathrm{~Hz}, 2 \mathrm{H}), 7.80(\mathrm{~d}$, $J=8.0 \mathrm{~Hz}, 2 \mathrm{H}), 7.60(\mathrm{~d}, J=8.4 \mathrm{~Hz}, 2 \mathrm{H}), 7.37(\mathrm{t}, J=7.8 \mathrm{~Hz}, 2 \mathrm{H}), 7.13(\mathrm{t}, J=7.2 \mathrm{~Hz}, 1 \mathrm{H}), 4.10(\mathrm{~s}, 2 \mathrm{H}), 3.72$ $(\mathrm{s}, 3 \mathrm{H}) \mathrm{ppm} .{ }^{13} \mathrm{C}-\mathrm{NMR}\left(\mathrm{DMSO}-d_{6}\right): \delta 173.41,172.35,165.37,164.44,138.93,137.47,136.33,129.45,128.67$, $128.62,123.87,120.49,112.39,75.79,52.41,32.24$ ppm. HRMS (EI) calc. for $\mathrm{C}_{20} \mathrm{H}_{15} \mathrm{~N}_{3} \mathrm{O}_{4} \mathrm{~S}^{+} 393.0783$; found 393.0782 .

Methyl (Z)-2-cyano-2-(4-oxo-3-(4-(o-tolylcarbamoyl)phenyl)thiazolidin-2-ylidene)acetate (29). White solid, Yield: $50 \%$. Mp 274.1-275.0 ${ }^{\circ} \mathrm{C} ;{ }^{1} \mathrm{H}-\mathrm{NMR}$ (DMSO- $d_{6}$ ): $\delta 10.05(\mathrm{~s}, 1 \mathrm{H}), 8.12(\mathrm{~d}, J=8.4 \mathrm{~Hz}, 2 \mathrm{H}), 7.59$ (d, $J=8.4 \mathrm{~Hz}, 2 \mathrm{H}), 7.36(\mathrm{~d}, J=7.6 \mathrm{~Hz}, 1 \mathrm{H}), 7.29(\mathrm{~d}, J=7.2 \mathrm{~Hz}, 1 \mathrm{H}), 7.24(\mathrm{t}, J=6.8 \mathrm{~Hz}, 1 \mathrm{H}), 7.19(\mathrm{t}, J=7.4 \mathrm{~Hz}$, $1 \mathrm{H}), 4.10(\mathrm{~s}, 2 \mathrm{H}), 3.72(\mathrm{~s}, 3 \mathrm{H}), 2.25(\mathrm{~s}, 3 \mathrm{H}) \mathrm{ppm} .{ }^{13} \mathrm{C}-\mathrm{NMR}$ (DMSO- $\left.d_{6}\right): \delta 173.44,172.35,165.38,164.28$, 137.45, 136.17, 135.95, 133.82, 130.33, 129.47, 128.62, 126.70, 126.16, 126.03, 112.43, 75.78, 52.41, 30.67, 17.89 ppm. HRMS (EI) calc. for $\mathrm{C}_{21} \mathrm{H}_{17} \mathrm{~N}_{3} \mathrm{O}_{4} \mathrm{~S}^{+}$407.0940; found 407.0941.

Methyl (Z)-2-cyano-2-(3-(4-((4-fluorophenyl)carbamoyl)phenyl)-4-oxothiazolidin-2-ylidene)acetate (30). White solid, Yield: $43 \%$. Mp 231.7-232.5 ${ }^{\circ} \mathrm{C} ;{ }^{1} \mathrm{H}-\mathrm{NMR}\left(\mathrm{DMSO}-\mathrm{d}_{6}\right): \delta 10.46(\mathrm{~s}, 1 \mathrm{H}), 8.10(\mathrm{~d}, J=8.4 \mathrm{~Hz}, 2 \mathrm{H})$, $7.82(\mathrm{dd}, J=8.8,5.0 \mathrm{~Hz}, 2 \mathrm{H}), 7.60(\mathrm{~d}, J=8.4 \mathrm{~Hz}, 2 \mathrm{H}), 7.22(\mathrm{t}, J=8.8 \mathrm{~Hz}, 2 \mathrm{H}), 4.10(\mathrm{~s}, 2 \mathrm{H}), 3.72(\mathrm{~s}$, $3 \mathrm{H}) \mathrm{ppm} .{ }^{13} \mathrm{C}-\mathrm{NMR}\left(\mathrm{DMSO}-d_{6}\right): \delta 173.40,172.34,165.36,164.38,158.39\left(\mathrm{~d},{ }^{1} J_{\mathrm{CF}}=239.1 \mathrm{~Hz}\right), 137.51$, $136.17,135.28\left(\mathrm{~d},{ }^{4} J_{\mathrm{CF}}=2.5 \mathrm{~Hz}\right), 129.47,128.65,122.33\left(\mathrm{~d},{ }^{3} J_{\mathrm{CF}}=7.8 \mathrm{~Hz}\right), 115.21\left(\mathrm{~d},{ }^{2} J_{\mathrm{CF}}=22.1 \mathrm{~Hz}\right)$, 112.40, 75.79, 52.40, 32.24 ppm. ${ }^{19} \mathrm{~F}-\mathrm{NMR}$ (DMSO- $d_{6}$ ): $\delta-118.51--118.61$ (m, $\left.1 \mathrm{~F}\right)$ ppm. HRMS (EI) calc. for $\mathrm{C}_{20} \mathrm{H}_{14} \mathrm{FN}_{3} \mathrm{O}_{4} \mathrm{~S}^{+}$411.0689; found 411.0690.

Methyl (Z)-2-cyano-2-(3-(4-((3-cyano-4-fluorophenyl)carbamoyl)phenyl)-4-oxothiazolidin-2-ylidene)acetate (31). White solid, Yield: $40 \%$. Mp 264.2-265.1 ${ }^{\circ} \mathrm{C} ;{ }^{1} \mathrm{H}-\mathrm{NMR}$ (DMSO- $d_{6}$ ): $\delta 10.75(\mathrm{~s}, 1 \mathrm{H}), 8.31$ (dd, $J=5.8,2.6 \mathrm{~Hz}, 1 \mathrm{H}), 8.11(\mathrm{~d}, J=8.4 \mathrm{~Hz}, 3 \mathrm{H}), 7.63(\mathrm{~d}, J=8.4 \mathrm{~Hz}, 2 \mathrm{H}), 7.57(\mathrm{t}, J=9.2 \mathrm{~Hz}, 1 \mathrm{H}), 4.10(\mathrm{~s}, 2 \mathrm{H})$, $3.73(\mathrm{~s}, 3 \mathrm{H}) \mathrm{ppm} .{ }^{13} \mathrm{C}-\mathrm{NMR}\left(\mathrm{DMSO}-d_{6}\right): \delta 173.39,172.30,165.34,164.80,158.49\left(\mathrm{~d},{ }^{1} J_{\mathrm{CF}}=251.2 \mathrm{~Hz}\right)$, $137.85,136.05\left(\mathrm{~d},{ }^{3} J_{\mathrm{CF}}=6.5 \mathrm{~Hz}\right), 135.57,129.61,128.76,127.79\left(\mathrm{~d},{ }^{3} J_{\mathrm{CF}}=8.1 \mathrm{~Hz}\right), 124.38,116.99\left(\mathrm{~d},{ }^{2} J_{\mathrm{CF}}\right.$ 
$=20.4 \mathrm{~Hz}), 113.95,112.42,99.85\left(\mathrm{~d},{ }^{2} J_{\mathrm{CF}}=16.1 \mathrm{~Hz}\right), 75.79,52.41,32.25 \mathrm{ppm} .{ }^{19} \mathrm{~F}-\mathrm{NMR}\left(\mathrm{DMSO}-d_{6}\right): \delta$ -114.31--114.38 (m, 1F) ppm. HRMS (EI) calc. for $\mathrm{C}_{21} \mathrm{H}_{13} \mathrm{FN}_{4} \mathrm{O}_{4} \mathrm{~S}^{+} 436.0642$; found 436.0640 .

Methyl (Z)-2-(3-(4-((4-chlorophenyl)carbamoyl)phenyl)-4-oxothiazolidin-2-ylidene)-2-cyanoacetate (32). White solid, Yield: $44 \%$. Mp 280.1-280.9 ${ }^{\circ} \mathrm{C} ;{ }^{1} \mathrm{H}-\mathrm{NMR}\left(\mathrm{DMSO}-d_{6}\right): \delta 10.53(\mathrm{~s}, 1 \mathrm{H}), 8.10(\mathrm{~d}, J=8.4 \mathrm{~Hz}, 2 \mathrm{H})$, $7.85(\mathrm{~d}, J=8.8 \mathrm{~Hz}, 2 \mathrm{H}), 7.61(\mathrm{~d}, J=8.4 \mathrm{~Hz}, 2 \mathrm{H}), 7.43(\mathrm{~d}, J=8.8 \mathrm{~Hz}, 2 \mathrm{H}), 4.10(\mathrm{~s}, 2 \mathrm{H}), 3.72(\mathrm{~s}, 3 \mathrm{H}) \mathrm{ppm}$. ${ }^{13}$ C-NMR (DMSO- $d_{6}$ ): $\delta$ 173.40, 172.33, 165.36, 164.57, 137.92, 137.60, 136.07, 129.50, 128.72, 128.55, $127.49,121.96,112.40,75.79,52.41,32.24$ ppm. HRMS (EI) calc. for $\mathrm{C}_{20} \mathrm{H}_{14}{ }^{35} \mathrm{ClN}_{3} \mathrm{O}_{4} \mathrm{~S}^{+}$427.0394; found 427.0393; calc. for $\mathrm{C}_{20} \mathrm{H}_{14}{ }^{37} \mathrm{ClN}_{3} \mathrm{O}_{4} \mathrm{~S}^{+} 429.0364$; found 429.0369 .

Methyl (Z)-2-(3-(4-((4-bromophenyl)carbamoyl)phenyl)-4-oxothiazolidin-2-ylidene)-2-cyanoacetate (33). White solid, Yield: $42 \%$. Mp 306.2-307.1 ${ }^{\circ} \mathrm{C} ;{ }^{1} \mathrm{H}-\mathrm{NMR}$ (DMSO- $\left.d_{6}\right): \delta 10.53(\mathrm{~s}, 1 \mathrm{H}), 8.10(\mathrm{~d}, J=8.4 \mathrm{~Hz}, 2 \mathrm{H})$, $7.80(\mathrm{~d}, J=8.8 \mathrm{~Hz}, 2 \mathrm{H}), 7.61(\mathrm{~d}, J=8.4 \mathrm{~Hz}, 2 \mathrm{H}), 7.57(\mathrm{~d}, J=8.8 \mathrm{~Hz}, 2 \mathrm{H}), 4.10(\mathrm{~s}, 2 \mathrm{H}), 3.73(\mathrm{~s}, 3 \mathrm{H}) \mathrm{ppm}$. ${ }^{13}$ C-NMR (DMSO- $d_{6}$ ): $\delta 173.39,172.32,165.36,164.58,138.35,137.61,136.07,131.46,129.50,128.73$, $122.32,115.58,112.40,75.80,52.41,32.25$ ppm. HRMS (EI) calc. for $\mathrm{C}_{20} \mathrm{H}_{14}{ }^{79} \mathrm{BrN}_{3} \mathrm{O}_{4} \mathrm{~S}^{+}$470.9888; found 470.9887; calc. for $\mathrm{C}_{20} \mathrm{H}_{14}{ }^{81} \mathrm{BrN}_{3} \mathrm{O}_{4} \mathrm{~S}^{+} 472.9868$; found 472.9863 .

Methyl (Z)-2-cyano-2-(3-(4-((4-iodophenyl)carbamoyl)phenyl)-4-oxothiazolidin-2-ylidene)acetate (34). White solid, Yield: $45 \%$. Mp 315.8-316.6 ${ }^{\circ} \mathrm{C} ;{ }^{1} \mathrm{H}-\mathrm{NMR}$ (DMSO- $\left.d_{6}\right): \delta 10.49(\mathrm{~s}, 1 \mathrm{H}), 8.09(\mathrm{~d}, J=8.8 \mathrm{~Hz}, 2 \mathrm{H})$, $7.72(\mathrm{~d}, J=8.8 \mathrm{~Hz}, 2 \mathrm{H}), 7.66(\mathrm{~d}, J=8.8 \mathrm{~Hz}, 2 \mathrm{H}), 7.60(\mathrm{~d}, J=8.8 \mathrm{~Hz}, 2 \mathrm{H}), 4.10(\mathrm{~s}, 2 \mathrm{H}), 3.72(\mathrm{~s}, 3 \mathrm{H}) \mathrm{ppm}$. ${ }^{13}$ C-NMR (DMSO- $\left.d_{6}\right): \delta 173.39,172.32,165.36,164.56,138.82,137.59,137.30,136.09,129.49,128.72$, 122.56, 112.40, 87.64, 75.79, 52.42, 32.25 ppm. HRMS (EI) calc. for $\mathrm{C}_{20} \mathrm{H}_{14} \mathrm{IN}_{3} \mathrm{O}_{4} \mathrm{~S}^{+}$518.9750; found 518.9751.

Methyl (Z)-2-cyano-2-(4-oxo-3-(4-((4-(trifluoromethyl)phenyl)carbamoyl)phenyl)thiazolidin-2-ylidene) acetate (35). White solid, Yield: $40 \%$. Mp 264.2-265.1 ${ }^{\circ} \mathrm{C} ;{ }^{1} \mathrm{H}-\mathrm{NMR}$ (DMSO- $\left.d_{6}\right): \delta 10.75(\mathrm{~s}, 1 \mathrm{H}), 8.13(\mathrm{~d}$, $J=8.0 \mathrm{~Hz}, 2 \mathrm{H}), 8.05(\mathrm{~d}, J=8.4 \mathrm{~Hz}, 2 \mathrm{H}), 7.76(\mathrm{~d}, J=8.4 \mathrm{~Hz}, 2 \mathrm{H}), 7.63(\mathrm{~d}, J=8.0 \mathrm{~Hz}, 2 \mathrm{H}), 4.11(\mathrm{~s}, 2 \mathrm{H}), 3.73$ (s, 3H) ppm. ${ }^{13} \mathrm{C}-\mathrm{NMR}\left(\mathrm{DMSO}_{\mathrm{d} 6}\right): \delta 173.40,172.33,165.36,165.00,142.61,137.78,135.87,129.55,128.85$, $125.93\left(\mathrm{q},{ }^{3} J_{\mathrm{CF}}=3.6 \mathrm{~Hz}\right), 124.35\left(\mathrm{q},{ }^{1} J_{\mathrm{CF}}=269.5 \mathrm{~Hz}\right), 123.80\left(\mathrm{q},{ }^{2} J_{\mathrm{CF}}=31.8 \mathrm{~Hz}\right), 120.23,112.42,75.78$, 52.40, 32.25 ppm. ${ }^{19} \mathrm{~F}-\mathrm{NMR}$ (DMSO- $d_{6}$ ): $\delta-60.35$ (s, 3F) ppm. HRMS (EI) calc. for $\mathrm{C}_{21} \mathrm{H}_{14} \mathrm{~F}_{3} \mathrm{~N}_{3} \mathrm{O}_{4} \mathrm{~S}^{+}$ 461.0657; found 461.0658 .

Methyl (Z)-2-cyano-2-(3-(4-((4-methoxyphenyl)carbamoyl)phenyl)-4-oxothiazolidin-2-ylidene)acetate (36). White solid, Yield: $55 \%$. Mp 268.9-269.7 ${ }^{\circ} \mathrm{C} ;{ }^{1} \mathrm{H}-\mathrm{NMR}$ (DMSO- $d_{6}$ ): $\delta 10.29(\mathrm{~s}, 1 \mathrm{H}), 8.10(\mathrm{~d}, J=7.2 \mathrm{~Hz}$, $2 \mathrm{H}), 7.71(\mathrm{~d}, J=8.0 \mathrm{~Hz}, 2 \mathrm{H}), 7.59(\mathrm{~d}, J=7.2 \mathrm{~Hz}, 2 \mathrm{H}), 6.95(\mathrm{~d}, J=8.0 \mathrm{~Hz}, 2 \mathrm{H}), 4.10(\mathrm{~s}, 2 \mathrm{H}), 3.76(\mathrm{~s}, 3 \mathrm{H})$, $3.73(\mathrm{~s}, 3 \mathrm{H}) \mathrm{ppm} .{ }^{13} \mathrm{C}-\mathrm{NMR}\left(\mathrm{DMSO}-d_{6}\right): \delta 173.37,172.31,165.36,163.96,155.69,137.32,136.40,131.97$, $129.39,128.53,122.10,113.76,112.35,75.83,55.17,52.38,32.21$ ppm. HRMS (EI) calc. for $\mathrm{C}_{21} \mathrm{H}_{17} \mathrm{~N}_{3} \mathrm{O}_{5} \mathrm{~S}^{+}$ 423.0889; found 423.0891 .

Methyl (Z)-2-(3-(4-((4-(tert-butyl)phenyl)carbamoyl)phenyl)-4-oxothiazolidin-2-ylidene)-2-cyanoacetate (37). White solid, Yield: 51\%. Mp 256.1-257.0 ${ }^{\circ} \mathrm{C} ;{ }^{1} \mathrm{H}-\mathrm{NMR}$ (DMSO- $\left.d_{6}\right): \delta 10.34(\mathrm{~s}, 1 \mathrm{H}), 8.10(\mathrm{~d}, J=8.4 \mathrm{~Hz}$, $2 \mathrm{H}), 7.71(\mathrm{~d}, J=8.8 \mathrm{~Hz}, 2 \mathrm{H}), 7.59(\mathrm{~d}, J=8.4 \mathrm{~Hz}, 2 \mathrm{H}), 7.39(\mathrm{~d}, J=8.8 \mathrm{~Hz}, 2 \mathrm{H}), 4.10(\mathrm{~s}, 2 \mathrm{H}), 3.72(\mathrm{~s}, 3 \mathrm{H})$, $1.29(\mathrm{~s}, 9 \mathrm{H}) \mathrm{ppm} .{ }^{13} \mathrm{C}-\mathrm{NMR}$ (DMSO- $d_{6}$ ): $\delta 173.42,172.38,165.37,164.21,146.19,137.40,136.35,129.42$, $128.63,125.24,120.23,112.39,75.74,52.41,34.06,32.25,31.18$ ppm. HRMS (EI) calc. for $\mathrm{C}_{24} \mathrm{H}_{23} \mathrm{~N}_{3} \mathrm{O}_{4} \mathrm{~S}^{+}$ 449.1409; found 449.1410 .

Methyl (Z)-2-cyano-2-(3-(4-(naphthalen-2-ylcarbamoyl)phenyl)-4-oxothiazolidin-2-ylidene)acetate (38). White solid, Yield: $48 \%$. Mp 285.0-286.0 ${ }^{\circ} \mathrm{C} ;{ }^{1} \mathrm{H}-\mathrm{NMR}$ (DMSO- $\left.d_{6}\right): \delta 10.61(\mathrm{~s}, 1 \mathrm{H}), 8.49(\mathrm{~d}, J=1.2 \mathrm{~Hz}, 1 \mathrm{H}), 8.16$ $(\mathrm{d}, J=8.4 \mathrm{~Hz}, 2 \mathrm{H}), 7.95-7.84(\mathrm{~m}, 4 \mathrm{H}), 7.63(\mathrm{t}, J=8.4 \mathrm{~Hz}, 2 \mathrm{H}), 7.51(\mathrm{t}, J=7.4 \mathrm{~Hz}, 1 \mathrm{H}), 7.45(\mathrm{t}, J=7.4 \mathrm{~Hz}$, 1H), $4.11(\mathrm{~s}, 2 \mathrm{H}), 3.73(\mathrm{~s}, 3 \mathrm{H}) \mathrm{ppm} .{ }^{13} \mathrm{C}-\mathrm{NMR}\left(\mathrm{DMSO}_{\mathrm{d} 6}\right): \delta 173.41,172.35,165.38,164.66,137.55,136.57$, 136.27, 133.27, 130.07, 129.50, 128.73, 128.18, 127.44, 126.40, 124.88, 120.96, 116.78, 112.41, 75.81, 52.41, 32.25 ppm. HRMS (EI) calc. for $\mathrm{C}_{24} \mathrm{H}_{17} \mathrm{~N}_{3} \mathrm{O}_{4} \mathrm{~S}^{+}$443.0940; found 443.0938 .

Methyl (Z)-2-(3-(4-(benzylcarbamoyl)phenyl)-4-oxothiazolidin-2-ylidene)-2-cyanoacetate (39). White solid, Yield: $68 \%$. Mp 117.3-118.1 ${ }^{\circ} \mathrm{C} ;{ }^{1} \mathrm{H}-\mathrm{NMR}\left(\mathrm{DMSO}_{6}\right)$ ): $\delta 9.22(\mathrm{t}, J=5.6 \mathrm{~Hz}, 1 \mathrm{H}), 8.03(\mathrm{~d}, J=8.4 \mathrm{~Hz}$, 
$2 \mathrm{H}), 7.54(\mathrm{~d}, J=8.4 \mathrm{~Hz}, 2 \mathrm{H}), 7.37-7.32(\mathrm{~m}, 4 \mathrm{H}), 7.27-7.22(\mathrm{~m}, 1 \mathrm{H}), 4.51(\mathrm{~d}, J=5.6 \mathrm{~Hz}, 2 \mathrm{H}), 4.08(\mathrm{~s}, 2 \mathrm{H})$, $3.71(\mathrm{~s}, 3 \mathrm{H}) \mathrm{ppm} .{ }^{13} \mathrm{C}-\mathrm{NMR}\left(\mathrm{DMSO}-d_{6}\right): \delta 173.39,172.35,165.37,165.20,139.46,137.20,135.82,129.39$, $128.28,128.23,127.27,126.78,112.33,75.78,52.39,42.72,32.22$ ppm. HRMS (EI) calc. for $\mathrm{C}_{21} \mathrm{H}_{17} \mathrm{~N}_{3} \mathrm{O}_{4} \mathrm{~S}^{+}$ 407.0940; found 407.0939.

Methyl (Z)-2-(3-(4-((5-acetylnaphthalen-2-yl)carbamoyl)phenyl)-4-oxothiazolidin-2-ylidene)-2-cyanoacetate (45). White solid, Yield: $43 \%$. Mp 275.0-275.8 ${ }^{\circ} \mathrm{C} ;{ }^{1} \mathrm{H}-\mathrm{NMR}$ (DMSO- $d_{6}$ ): $\delta 10.73(\mathrm{~s}, 1 \mathrm{H}), 9.10$ (d, $J=1.6 \mathrm{~Hz}, 1 \mathrm{H}), 8.17(\mathrm{~d}, J=8.4 \mathrm{~Hz}, 2 \mathrm{H}), 8.12(\mathrm{~d}, J=7.2 \mathrm{~Hz}, 1 \mathrm{H}), 8.11-8.08(\mathrm{~m}, 2 \mathrm{H}), 8.01(\mathrm{~d}, J=8.8 \mathrm{~Hz}$, $1 \mathrm{H}), 7.62(\mathrm{~d}, J=8.4 \mathrm{~Hz}, 2 \mathrm{H}), 7.53(\mathrm{t}, J=7.8 \mathrm{~Hz}, 1 \mathrm{H}), 4.11(\mathrm{~s}, 2 \mathrm{H}), 3.73(\mathrm{~s}, 3 \mathrm{H}), 2.74(\mathrm{~s}, 3 \mathrm{H}) \mathrm{ppm} .{ }^{13} \mathrm{C}-\mathrm{NMR}$ (DMSO-d $d_{6}$ ): $\delta 201.53,173.40,172.34,165.37,164.72,138.60,137.59,136.18,134.45,132.43,130.57,129.84$, $129.60,129.45,128.85,128.81,123.62,121.26,115.06,112.38,75.82,52.40,32.25,30.08$ ppm. HRMS (EI) calc. for $\mathrm{C}_{26} \mathrm{H}_{19} \mathrm{~N}_{3} \mathrm{O}_{5} \mathrm{~S}^{+} 485.1045$; found 485.1046 .

\subsubsection{Synthesis of Compounds 42,43 and 46}

Synthesis of (Z)-2-((4-(2-(1-cyano-2-methoxy-2-oxoethylidene)-4-oxothiazolidin-3yl)benzamido)methyl)-benzoic acid (42)

TCDI (2.4 mmol) was added to a solution of compound IM in THF $(10 \mathrm{~mL})$. Then the mixture was stirred at room temperature for $3 \mathrm{~h}$. Then the mixture was added compound $\mathbf{4 2 b}(2 \mathrm{mmol})$ and stirred at $50{ }^{\circ} \mathrm{C}$ for $2 \mathrm{~h}$. The solvent was removed under reduced pressure after cooling to room temperature and the residue was purified by column chromatography $(\mathrm{DCM} / \mathrm{MeOH}=20: 3, \mathrm{~V} / \mathrm{V})$ to give 42 in a yield of $38 \%$. White solid, Yield: $38 \%$. Mp 217.3-218.1 ${ }^{\circ} \mathrm{C} ;{ }^{1} \mathrm{H}-\mathrm{NMR}$ (DMSO- $\left.d_{6}\right): \delta 13.08(\mathrm{~s}, 1 \mathrm{H}), 9.14(\mathrm{t}, J=$ $5.6 \mathrm{~Hz}, 1 \mathrm{H}), 8.04(\mathrm{~d}, J=8.4 \mathrm{~Hz}, 2 \mathrm{H}), 7.90(\mathrm{~d}, J=7.6 \mathrm{~Hz}, 1 \mathrm{H}), 7.58-7.52(\mathrm{~m}, 3 \mathrm{H}), 7.43(\mathrm{~d}, J=7.6 \mathrm{~Hz}, 1 \mathrm{H})$, $7.37(\mathrm{t}, J=7.6 \mathrm{~Hz}, 1 \mathrm{H}), 4.85(\mathrm{~d}, J=5.6 \mathrm{~Hz}, 2 \mathrm{H}), 4.09(\mathrm{~s}, 2 \mathrm{H}), 3.71(\mathrm{~s}, 3 \mathrm{H}) \mathrm{ppm} .{ }^{13} \mathrm{C}-\mathrm{NMR}\left(\mathrm{DMSO}-d_{6}\right): \delta$ $173.93,172.89,168.93,165.92,165.87,140.81,137.76,136.24,132.51,130.87,129.94,128.74,127.76,127.22$, 112.86, 76.22, 52.90, 41.80, 32.73 ppm. HRMS (EI) calc. for $\mathrm{C}_{22} \mathrm{H}_{17} \mathrm{~N}_{3} \mathrm{O}_{6} \mathrm{~S}^{+} 451.0844$; found 451.0838.

Synthesis of (Z)-3-((4-(2-(1-cyano-2-methoxy-2-oxoethylidene)-4-oxothiazolidin-3yl)benzamido)methyl) benzoic acid (43)

$\mathrm{CF}_{3} \mathrm{COOH}(1.5 \mathrm{~mL})$ was added to a solution of compound $43 \mathrm{c}(1 \mathrm{mmol})$ in DCM $(15 \mathrm{~mL})$. Then the mixture was stirred at room temperature overnight. The solvent was removed under reduced pressure and the residue was crystallized from $\mathrm{DCM} / \mathrm{MeOH}$ to give compound 43 in a yield of $85 \%$.

White solid, Mp 205.7-206.6 ${ }^{\circ} \mathrm{C} ;{ }^{1} \mathrm{H}-\mathrm{NMR}\left(\mathrm{DMSO}-d_{6}\right): \delta 12.92(\mathrm{~s}, 1 \mathrm{H}), 9.26(\mathrm{t}, J=5.6 \mathrm{~Hz}, 1 \mathrm{H}), 8.02$ $(\mathrm{d}, J=8.4 \mathrm{~Hz}, 2 \mathrm{H}), 7.94(\mathrm{~s}, 1 \mathrm{H}), 7.84(\mathrm{~d}, J=8.0 \mathrm{~Hz}, 1 \mathrm{H}), 7.59(\mathrm{~d}, J=7.6 \mathrm{~Hz}, 1 \mathrm{H}), 7.54(\mathrm{~d}, J=8.4 \mathrm{~Hz}, 2 \mathrm{H})$, $7.47(\mathrm{t}, J=8.0 \mathrm{~Hz}, 1 \mathrm{H}), 4.56(\mathrm{~d}, J=5.6 \mathrm{~Hz}, 2 \mathrm{H}), 4.09(\mathrm{~s}, 2 \mathrm{H}), 3.71(\mathrm{~s}, 3 \mathrm{H}) \mathrm{ppm} .{ }^{13} \mathrm{C}-\mathrm{NMR}\left(\mathrm{DMSO}-d_{6}\right)$ : $\delta$ 173.34, 172.29, 167.22, 165.34, 165.25, 139.96, 137.26, 135.68, 131.88, 130.84, 129.42, 128.57, 128.24, $128.21,127.81,112.30,75.81,52.37,42.53,32.19$ ppm. HRMS (ESI) calc. for $\mathrm{C}_{22} \mathrm{H}_{17} \mathrm{~N}_{3} \mathrm{O}_{6} \mathrm{SNa}^{+}(\mathrm{M}+$ $\mathrm{Na})^{+}, 474.0736$; found 474.0737 .

Synthesis of 2-(((E)-(4-((Z)-2-(1-cyano-2-methoxy-2-oxoethylidene)-4-oxothiazolidin-3-yl)benzamido)methylene)amino)benzoic acid (46)

A drop of concentrated $\mathrm{HCl}$ was added to a solution of compound $46 \mathrm{~b}(1 \mathrm{mmol})$ and 2-formylbenzoic acid in $\mathrm{EtOH}(30 \mathrm{~mL})$. Then the mixture was stirred at room temperature until the reaction was completed. The solvent was removed under reduced pressure and the residue was crystallized from DCM/MeOH to give compound 46 in yield of $80 \%$. White solid, Yield: $80 \%$. Mp 222.8-223.5 ${ }^{\circ} \mathrm{C} ;{ }^{1} \mathrm{H}-\mathrm{NMR}$ (DMSO- $\left.d_{6}\right): \delta 13.26(\mathrm{~s}, 1 \mathrm{H}), 12.25(\mathrm{~s}, 1 \mathrm{H}), 9.24(\mathrm{~s}, 1 \mathrm{H}), 8.12-8.05(\mathrm{~m}, 3 \mathrm{H}), 7.92$ $(\mathrm{d}, J=7.6 \mathrm{~Hz}, 1 \mathrm{H}), 7.67(\mathrm{t}, J=7.6 \mathrm{~Hz}, 1 \mathrm{H}), 7.60(\mathrm{~d}, J=8.4 \mathrm{~Hz}, 2 \mathrm{H}), 7.55(\mathrm{t}, J=7.6 \mathrm{~Hz}, 1 \mathrm{H}), 4.10(\mathrm{~s}, 2 \mathrm{H})$, $3.72(\mathrm{~s}, 3 \mathrm{H}) \mathrm{ppm} .{ }^{13} \mathrm{C}-\mathrm{NMR}$ (DMSO- $d_{6}$ ): $\delta 173.39,172.33,168.04,165.36,162.28,147.08,137.63,134.78$, 134.53, 132.00, 130.67, 130.30, 129.69, 129.51, 128.72, 126.68, 112.35, 75.80, 52.40, 32.24 ppm. HRMS (ESI) calc. for $\mathrm{C}_{22} \mathrm{H}_{16} \mathrm{~N}_{4} \mathrm{O}_{6} \mathrm{SNa}^{+}(\mathrm{M}+\mathrm{Na})^{+}, 487.0688$; found 487.0689. 


\subsection{In Vitro Assays}

The plasmid pET-19b- $h$ DHODH (Met30-Arg396) was transformed into BL21 (DE3) E. coli cells for protein production. Cells were grown at $37^{\circ} \mathrm{C}$ in a rich medium, and were induced with $1 \mathrm{mM}$ isopropyl- $\beta$-D-thiogalactoside (IPTG) at an $\mathrm{OD}_{600}$ of $0.6-0.8$. After incubation for an additional $18 \mathrm{~h}$ at $16{ }^{\circ} \mathrm{C}$, the cells were harvested by centrifugation. The harvested cells were suspended in buffer A (50 mM HEPES pH 8.0, $400 \mathrm{mM} \mathrm{NaCl}, 10 \%$ glycerol) and disrupted by a high-pressure cracker at $4{ }^{\circ} \mathrm{C}$. Triton X-100 was added to a final concentration of $1 \%$ into the lysate before centrifugation. The supernatant was loaded onto a HiTrap Chelating column ( $5 \mathrm{~mL}$; GE Healthcare, Uppsala, Sweden). Pure $h$ DHODH was eluted with buffer A, 0.1\% Triton X-100 and $160 \mathrm{mM}$ imidazole.

The purified $h \mathrm{DHODH}$ was diluted into a final concentration of $10 \mathrm{nM}$ with the assay buffer contained $50 \mathrm{mM}$ HEPES $\mathrm{pH}$ 8.0, $150 \mathrm{mM} \mathrm{KCl}, 0.1 \%$ Triton X-100. UQ $\mathrm{U}_{0}$ and DCIP were added to the assay buffer to final concentrations of 100 and $120 \mu \mathrm{M}$, respectively. The dihydroorotate was added to a final concentration of $500 \mu \mathrm{M}$ to initiate the reaction. Brequinar was measured as the positive control. Inhibition rate was calculated from $\left(1-V_{i} / V_{0}\right) \times 100$. For the determination of the $\mathrm{IC}_{50}$ values, eight to nine different concentrations were applied. Each inhibitor concentration point was tested in triplicate. IC50 values were calculated using the sigmoidal fitting option of the program Origin 8.0.

\section{Conclusions}

In conclusion, based on our previous work, three series of 4-thiazolidinone derivatives including biphenyl, diphenyl ether and amide groups were designed and synthesized as $h$ DHODH inhibitors. The preliminary structure-activity relationships were investigated. The $h \mathrm{DHODH}$ inhibitory activities of several newly synthesized compounds and compounds $\mathbf{7}$ and 8 are at the same level, especially compounds 9 and 37 with $\mathrm{IC}_{50}$ values of 1.32 and $1.45 \mu \mathrm{M}$, respectively. Further modifications will be investigated to improve the activity of 4-thiazolidinone derivatives.

Supplementary Materials: Spectrums for target compounds 7-46 could be accessed in supplementary materials.

Author Contributions: Conceptualization, X.X., L.Z. (Lili Zhu) and F.Z.; investigation, F.Z. and L.Q.; methodology, F.Z., L.Q., X.X., G.Y., T.Q., L.Z. (Letian Zhang) and S.L.; software, L.Q., F.Z., T.Q., S.L. and H.L.; data curation, X.X., F.Z., L.Q., G.Y. and L.Z. (Lili Zhu); writing—original draft preparation, F.Z. and G.Y.; writing-review and editing, X.X. and L.Z (Lili Zhu).; supervision, X.X. and L.Z. (Lili Zhu).

Funding: X.X. and H.L. innovation Program of Shanghai Municipal Education Commission (201701070002E00037). The Fundamental Research Funds for the Central Universities.

Conflicts of Interest: The authors declare no conflict of interest.

\section{References}

1. Surekha, K.; Prabhu, D.; Richard, M.; Nachiappan, M.; Biswal, J.; Jeyakanthan, J. Investigation of vital pathogenic target orotate phosphoribosyltransferases (OPRTase) from Thermus thermophilus HB8: Phylogenetic and molecular modeling approach. Gene 2016, 583, 102-111. [CrossRef] [PubMed]

2. Roon, D.E.N.V.; Jansen, T.L.T.A.; Houtman, N.M.; Spoelstra, P.; Brouwers, J.R.B.J. Leflunomide for the Treatment of Rheumatoid Arthritis in Clinical Practice. Am. J. Med. Sci. 2002, 323, 190-193.

3. Liu, S.; Neidhardt, E.A.; Grossman, T.H.; Ocain, T.; Clardy, J. Structures of human dihydroorotate dehydrogenase in complex with antiproliferative agents. Structure 2000, 8, 25-33. [CrossRef]

4. Jöckel, J.; Wendt, B.; Löffler, M. Structural and functional comparison of agents interfering with dihydroorotate, succinate and NADH oxidation of rat liver mitochondria. Biochem. Pharmacol. 1998, 56, 1053-1060. [CrossRef]

5. Breedveld, F.C.; Dayer, J.M. Leflunomide: Mode of action in the treatment of rheumatoid arthritis. Ann. Rheum. Dis. 2000, 59, 841-849. [CrossRef] [PubMed]

6. Löffler, M.; Fairbanks, L.D.; Zameitat, E.; Marinaki, A.M.; Simmonds, H.A. Pyrimidine pathways in health and disease. Trends Mol. Med. 2005, 11, 430-437. [CrossRef] [PubMed]

7. Rusai, K.; Schmaderer, C.; Baumann, M.; Chmielewski, S.; Prókai, Á.; Kis, E.; Szabó, A.J.; Leban, J.; Doblhofer, R.; Ammendola, A. Immunosuppression with 4SC-101, a novel inhibitor of dihydroorotate dehydrogenase, in a rat model of renal transplantation. Transplantation 2012, 93, 1101-1107. [CrossRef] [PubMed] 
8. Vyas, V.K.; Ghate, M. Recent developments in the medicinal chemistry and therapeutic potential of dihydroorotate dehydrogenase (DHODH) inhibitors. Mini Rev. Med. Chem. 2011, 11, 1039-1055. [CrossRef]

9. Sykes, D.B.; Kfoury, Y.S.; Mercier, F.E.; Wawer, M.J.; Law, J.M.; Haynes, M.K.; Lewis, T.A.; Schajnovitz, A.; Jain, E.; Lee, D. Inhibition of Dihydroorotate Dehydrogenase Overcomes Differentiation Blockade in Acute Myeloid Leukemia. Cell 2016, 167, 171-186. [CrossRef]

10. Dexter, D.L.; Hesson, D.P.; Ardecky, R.J.; Rao, G.V.; Tippett, D.L.; Dusak, B.A.; Paull, K.D.; Plowman, J.; DeLarco, B.M.; Narayanan, V. Activity of a novel 4-quinolinecarboxylic acid, NSC 368390 [6-fluoro-2-(2'-fluoro-1, 1'-biphenyl-4-yl)-3-methyl-4-quinolinecarboxylic acid sodium salt], against experimental tumors. Cancer Res. 1985, 45, 5563-5568.

11. Cramer, D.V.; Chapman, F.A.; Jaffee, B.D.; Jones, E.A.; Knoop, M.; Hreha-Eiras, G.; Makowka, L. The effect of a new immunosuppressive drug, brequinar sodium, on heart, liver, and kidney allograft rejection in the rat. Transplantation 1992, 53, 303-307. [CrossRef] [PubMed]

12. Scott, D.L.; Wolfe, F.; Huizinga, T.W.J. Rheumatoid arthritis. Lancet 2010, 376, 1094-1108. [CrossRef]

13. Dang, W.; Wang, W.; Chen, W.; Lian, F.; Li, L.; Ying, H.; Xu, Y.; Zhang, N.; Chen, Y.; Liu, M. Pharmacologic inhibition of dihydroorotate dehydrogenase induces apoptosis and differentiation in acute myeloid leukemia cells. Haematologica 2018, 103, 1472-1483.

14. Sainas, S.; Pippione, A.C.; Lupino, E.; Giorgis, M.; Circosta, P.; Gaidano, V.; Goyal, P.; Bonanni, D.; Rolando, B.; Cignetti, A. Targeting Myeloid Differentiation Using Potent 2-Hydroxypyrazolo [1,5-a]pyridine Scaffold-Based Human Dihydroorotate Dehydrogenase Inhibitors. J. Med. Chem. 2018, 61, 6034-6055. [CrossRef] [PubMed]

15. Munierlehmann, H.; Vidalain, P.O.; Tangy, F.; Janin, Y.L. On Dihydroorotate Dehydrogenases and Their Inhibitors and Uses. J. Med. Chem. 2013, 56, 3148-3167. [CrossRef] [PubMed]

16. Finckh, A.; Dehler, S.; Gabay, C. The effectiveness of leflunomide as a co-therapy of tumour necrosis factor inhibitors in rheumatoid arthritis: A population-based study. Ann. Rheum. Dis. 2009, 68, 33. [CrossRef] [PubMed]

17. Rückemann, K.; Fairbanks, L.D.; Carrey, E.A.; Hawrylowicz, C.M.; Richards, D.F.; Kirschbaum, B.; Simmonds, H.A. Leflunomide inhibits pyrimidine de novo synthesis in mitogen-stimulated T-lymphocytes from healthy humans. J. Biol. Chem. 1998, 273, 21682-21691. [CrossRef] [PubMed]

18. Christian, C.; Li, D.K.; Freedman, M.S.; Philippe, T.; Hadj, B.; Dazhe, W.; Amit, B.O.; Traboulsee, A.L.; Reiman, L.E.; O'Connor, P.W. Long-term follow-up of a phase 2 study of oral teriflunomide in relapsing multiple sclerosis: Safety and efficacy results up to 8.5 years. Mult. Scler. 2012, 18, 1278-1289.

19. Confavreux, C.; O'Connor, P.; Comi, G.; Freedman, M.S.; Miller, A.E.; Olsson, T.P.; Wolinsky, J.S.; Bagulho, T.; Delhay, J.L.; Dukovic, D. Oral teriflunomide for patients with relapsing multiple sclerosis (TOWER): A randomised, double-blind, placebo-controlled, phase 3 trial. Lancet Neurol. 2014, 13, 247-256. [CrossRef]

20. Claussen, M.C.; Korn, T. Immune mechanisms of new therapeutic strategies in MS: Teriflunomide. Clin. Immunol. 2012, 142, 49-56. [CrossRef]

21. Maroun, J.; Ruckdeschel, J.; Natale, R.; Morgan, R.; Dallaire, B.; Sisk, R.; Gyves, J. Multicenter phase II study of brequinar sodium in patients with advanced lung cancer. Cancer Chemother. Pharmacol. 1993, 32, 64-66. [CrossRef] [PubMed]

22. Dodion, P.F.; Wagener, T.; Stoter, G.; Drozd, A.; Lev, L.M.; Skovsgaard, T.; Renard, J.; Cavalli, F. Phase II trial with Brequinar (DUP-785, NSC 368390) in patients with metastatic colorectal cancer: A study of the Early Clinical Trials Group of the EORTC. Ann. Oncol. Off. J. Eur. Soc. Med. Oncol. 1990, 1, 79. [CrossRef]

23. Cramer, D.V.; Chapman, F.A.; Makowka, L. The use of brequinar sodium for transplantation. Ann. N. Y. Acad. Sci. 2010, 696, 216-226. [CrossRef] [PubMed]

24. Min, Q.; Gang, Z.; Wang, Q.Y.; Hao, Y.X.; Dong, H.; Yuan, Z.; Shi, P.Y. Characterization of Dengue Virus Resistance to Brequinar in Cell Culture. Antimicrob. Agents Chemother. 2010, 54, 3686-3695.

25. Schnellrath, L.C.; Damaso, C.R. Potent antiviral activity of brequinar against the emerging Cantagalo virus in cell culture. Int. J. Antimicrob. Agents 2011, 38, 435-441. [CrossRef] [PubMed]

26. Herrlinger, K.R.; Diculescu, M.; Fellermann, K.; Hartmann, H.; Howaldt, S.; Nikolov, R.; Petrov, A.; Reindl, W.; Otte, J.M.; Stoynov, S. Efficacy, safety and tolerability of vidofludimus in patients with inflammatory bowel disease: The ENTRANCE study. Gastroenterology 2013, 7, 636-643.

27. Fitzpatrick, L.R.; Ammendola, A. Vidofludimus Improves Colitis in Rats by a Dual Mode of Action. J. Pharmacol. Exp. Ther. 2012, 342, 850-860. [CrossRef] [PubMed] 
28. Fitzpatrick, L.R.; Small, J.S.; Doblhofer, R.; Henning, S.W.; Ammendola, A. P012 Vidofludimus inhibits IL-17 and improves hapten-induced colitis in young rats by a unique dual mode of action. J. Pharmacol. Exp. Ther. 2012, 142, 850-860. [CrossRef]

29. Lewis, T.A.; Sykes, D.B.; Law, J.M.; Muñoz, B.; Rustiguel, J.K.; Nonato, M.C.; Scadden, D.T.; Schreiber, S.L. Development of mL390: A Human DHODH Inhibitor That Induces Differentiation in Acute Myeloid Leukemia. ACS Med. Chem. Lett. 2016, 7, 1112. [CrossRef]

30. Mjgw, L.; Imm, V.L.; Drummond, C.J.; Chu, S.; Healy, A.R.; Popova, G.; Pastor, F.A.; Mollick, T.; Darekar, S.; Sedimbi, S.K. A DHODH inhibitor increases p53 synthesis and enhances tumor cell killing by p53 degradation blockage. Nat. Commun. 2018, 9, 1107.

31. Zeng, F.; Qi, T.; Li, C.; Li, T.; Li, H.; Li, S.L.; Zhu, L.; Xu, X. Synthesis, structure-activity relationship and binding mode analysis of 4-thiazolidinone derivatives as novel inhibitors of human dihydroorotate dehydrogenase. Medchemcomm 2017, 8, 1297-1302. [CrossRef] [PubMed]

32. Song, W.; Li, S.; Tong, Y.; Wang, J.; Quan, L.; Chen, Z.; Zhao, Z.; Xu, Y.; Zhu, L.; Qian, X. Structure-based design of potent human dihydroorotate dehydrogenase inhibitors as anticancer agents. Medchemcomm 2016, 7, 1441-1448. [CrossRef]

Sample Availability: Samples of the compounds 7-46 are available from the authors. 